\title{
Integrated Modelling of the Global Cobalt Extraction, Supply, Price and Depletion of Extractable Resources Using the WORLD6 Model
}

\author{
Harald Ulrik Sverdrup ${ }^{1}$ (D) Kristin Vala Ragnarsdottir ${ }^{2} \cdot$ Deniz Koca $^{3}$
}

Received: 4 October 2016 / Accepted: 11 January 2017 / Published online: 30 March 2017

(C) Springer International Publishing Switzerland 2017

\begin{abstract}
The global cobalt cycle in society was modelled using an integrated systems dynamics model, WORLD6, integrating several earlier system dynamics models developed by the authors. The COBALT sub-model was used to assess the long-term sufficiency of the available extractable cobalt and address the effect of different degrees of recycling on cobalt supply. The extraction of cobalt is mostly dependent on the extraction of copper, nickel and platinum group metals. The ultimately recoverable resources estimate was 32 million ton on land and 34 million ton on the ocean floors, a total of 66 million ton, significantly larger than earlier estimates. It is very uncertain how much of the cobalt, detected in ocean floor deposits, is extractable. The present use of cobalt by society is diverse and about half the total cobalt production to the market is in the form of metallic cobalt. The simulations show that cobalt extraction is predicted to reach a peak in the years 2025-2030 and that the supply will reach a peak level in 2040-2050. Three different global population scenarios were used (high, middle, low). We predict that the supply of cobalt will decline slowly with about 3-5\% per year after 2050 . The present use of cobalt in chemicals, colours, rechargeable batteries and super-alloys shows a low degree of recycling and the systemic losses are significant. After 2170, cobalt will have run out under business-as-usual scenario.
\end{abstract}

Harald Ulrik Sverdrup

hus@hi.is

1 Industrial Engineering, University of Iceland, VR2, Hjarðarhagi 6, 107 Reykjavik, Iceland

2 Institute of Earth Sciences, University of Iceland, Askja, 101 Reykjavik, Iceland

3 Center for Environmental and Climate Research, Lund University, 22362 Lund, Sweden
The present business-as-usual cobalt use in society is not sustainable. Too much cobalt is lost if only market mechanisms are expected to improve recycling, and unnecessary cobalt is wasted if no policy actions are taken. Increased recycling and better conservation will be able to improve the supply situation, but this will need active policy participation beyond what market mechanisms can do alone. To conserve cobalt for coming generations, present policies must be changed within the next few decades. The sooner policies change, the better for future generations.

Keywords Cobalt $\cdot$ Price $\cdot$ Reserves $\cdot$ Mining $\cdot$ Recycling $\cdot$ System dynamics

\section{Introduction}

The four most important strategic metals for human society are iron, aluminium, copper and zinc. The extraction of copper, zinc and lead is normally done from poly-metallic ores. We have earlier developed an integrated model (BRONZE) for copper, zinc and lead and some of the metals depending on them (Sverdrup et al. 2014b). Cobalt belongs to a series of technology metals, which are produced in small annual amounts and are used as key components in important technologies that society depends on. Cobalt production is at present $97 \%$ from secondary extraction. In the past, mining of cobalt was from small cobalt mines with rich ore grade in Germany, Norway and Canada.

Cobalt blue is well known and cobalt is used since ancient times as a pigment for glass. Georg Brandt, a Swedish scientist, was the first to isolate cobalt as a new metal (Brandt 1735, 1746, 1748). He detected that cobalt was the causative element in cobalt blue. Cobalt is a silvery, white metal, the specific density is $8.86 \mathrm{~g} / \mathrm{cm}^{3}$ and the melting 
point is high, $1495^{\circ} \mathrm{C}$. It is magnetic and resistant to corrosion. The earliest cobalt use was to colour glass, enamel and pottery.

One of the first industrial cobalt mines was located in Norway in the sixteenth century (Rosenqvist 1949; Liessmann 1994; Drake Resources 2015), but at the same time mines were developed in Sweden, Saxony (now a federal state in Germany) and Hungary. The first cobalt product was pigment for glass, later some of these mines also produced metal (Ramberg 2008). Today, there are few mines extracting cobalt only (Eckstrand and Hulbert 2007; USGS 2015). There is one mine in Morocco at Bou Azzer that produces about 1800 ton per year; it has been operating for many years. The reserves are stated at 20,000 ton, the total hidden resources are unknown, but they are with certainty significantly larger (Newman 2011; Shedd 2002, 2012, 2015). The other dedicated cobalt mine opened in 2013 in Idaho, USA, and will produce about 1500 ton per year of refined pure cobalt, about 1500 ton per year of copper and about $100 \mathrm{~kg}$ of gold per year. The ore grade is $0.6 \%$ for cobalt and considered as "high grade cobalt ore", $0.6 \%$ for copper and $0.5 \mathrm{~g}$ per ton rock for gold. The total resource is estimated to significantly more than 20,000 ton (Searle 2015).

Cobalt has many uses, the most important are listed in Table 1 together with their market share, assumed market prospects and profitability. Some authors have highlighted risks of resource depletion looming (Meadows et al. 1972, 1974, 2005; Heinberg 2001; Johnson et al. 2007; Eilu 2011; Gordon et al. 2006; Graedel et al. 2004; Graedel and Erdmann 2012; Roland 2015; UNEP 2011a, b, c, 2012, 2013a, b, c; Ragnarsdottir et al. 2012; Kwatra et al. 2012; Nassar et al. 2012; Bardi 2013; Elshakaki and Graedel 2013; Sverdrup et al. 2013; Eliott et al. 2014; Mohr et al. 2014a; Northey et al. 2014), a few also considering cobalt particularly (Alonso et al. 2007; UNEP 2011a, b, c, 2012, 2013a, b, c; Ragnarsdottir et al. 2012; Sverdrup et al. 2013; Sverdrup and Ragnaradottir 2014). About $55 \%$ of the cobalt extraction is a by-product of nickel extraction, $35 \%$ of the extraction is a by-product of copper production and $10 \%$ comes from other sources like platinum group metals extraction and chromium refining. Only $2.2 \%$ came from primary cobalt mining (Liessmann 1994; Hawkins 2001; Shedd 2002, 2012, 2015; Alonso et al. 2007; Eckstrand and Hulbert 2007; Slack et al. 2010; Mudd et al. 2013a, b; Dawkins et al. 2012). Figure 1a shows the cobalt mining production to date (data taken from USGS 2015). Figure 1b shows the metal production for the same time period, only about $65 \%$ the extracted amounts of cobalt is smelted into metallic form. Since year 2000, there has been a significant increase in metal production, which is used for super-alloys and specialty steels.

The new growing application for cobalt is for rechargeable accumulators (batteries) and in super-alloys for high-performance jet turbines. Cobalt is a significant and required component in nickel hydride and lithium ion batteries. A flowchart for cobalt is shown in Fig. 2 (note more elaborate flowchart for the whole system is given in Figs. 4, $5)$. A very small amount (3\%) comes from primary mining of cobalt, but this may be expected to increase in the future because of ongoing projects and mineral prospecting in unchartered areas of the World (USA, Canada, Morocco). In 1960, most cobalt was used for alloys, but the materials consumption has increased significantly after year 2000 . The cobalt use in chemicals is sharply rising with the production of larger lithium ion batteries, where cobalt is a major battery cell-stabilizing compound. The cobalt price has gone up in running prices, and it has fluctuated a lot since 1975. From 1945 to 1973 , cobalt was considered to be a strategic metal and trade was partly government controlled. During that period some countries had strategic stockpiles, and the market was not really free for cobalt. The market was thus not a free functioning, but one of partial command and control. Much of the cobalt originates from the copper-belt in Central Africa (about 50\%), and the volatility in the cobalt supply and price is a reflection of the troubled political situation in that region.
Table 1 Overview of different uses of cobalt

\begin{tabular}{lllllll}
\hline Product group & Form & $\begin{array}{l}\text { Fraction of } \\
\text { supply, } \%\end{array}$ & $\begin{array}{l}\text { Trend in use and since } \\
\text { when }\end{array}$ & Recycling & $\begin{array}{l}\text { Value } \\
\text { added to } \\
\text { product }\end{array}$ \\
\hline Super-alloys & Metallic & 22 & Increases & 1995 & Yes & High \\
Cutting tools & Metallic & 11 & Increases & 1960 & Partly & Medium \\
Magnets & Metallic & 12 & Increase & 1990 & Partly & High \\
Other applications & Metallic & 11 & Constant & - & No & Low \\
Batteries & Chemical & 22 & Increases & 2000 & Yes & Medium \\
Chemicals, catalyst & Chemical & 9 & Increases & 1960 & No & Low \\
Resins, pigments & Chemical & 13 & Constant & - & No & Low \\
\hline
\end{tabular}

The metallic uses take $56 \%$ of the supply, the other uses take $44 \%$ 

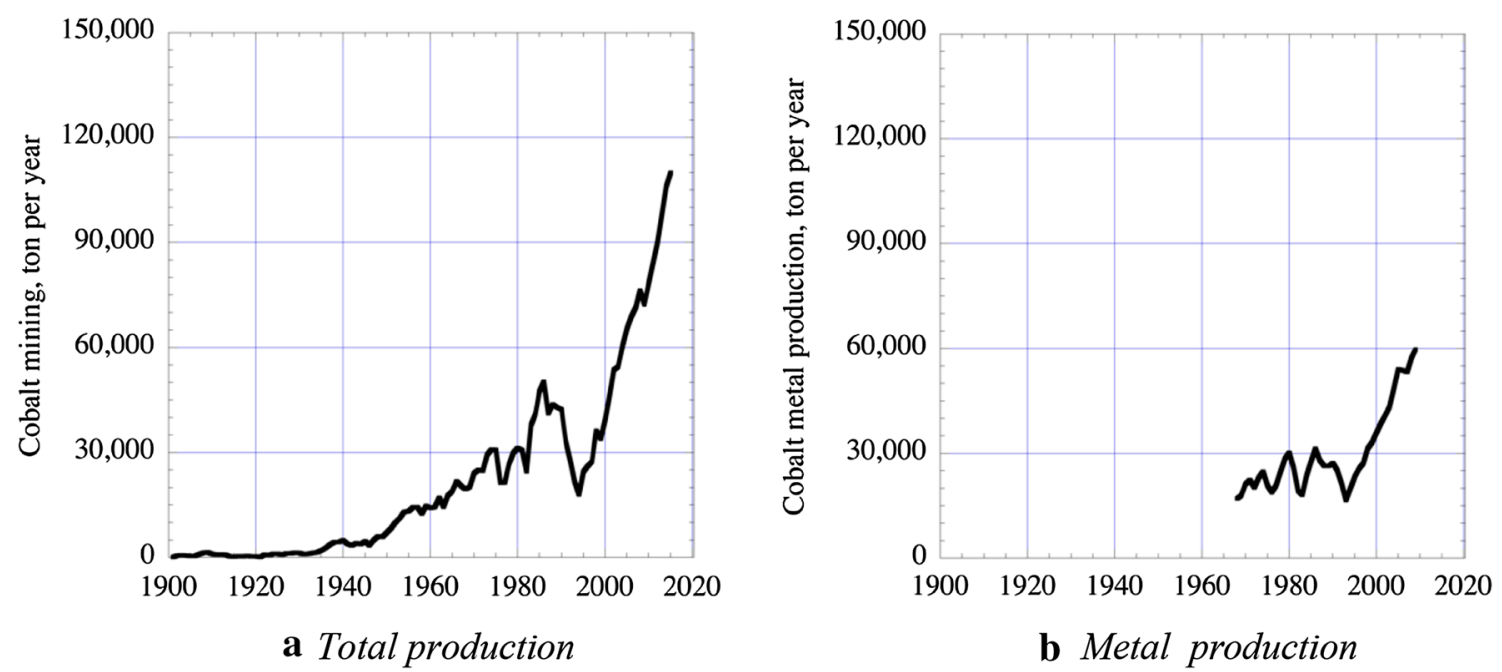

Fig. 1 a Cobalt production to date (USGS 2015). b Metal production for the same time period

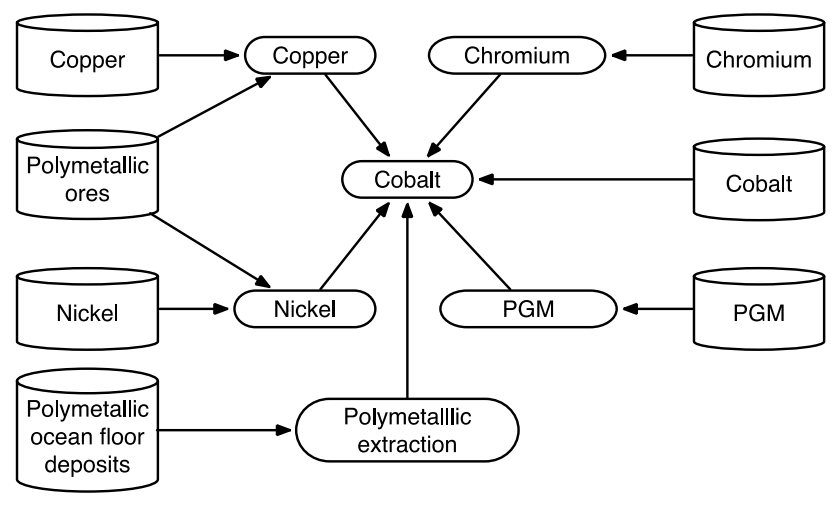

Fig. 2 Cobalt flow path from ores to society, from different types of deposits. Connection between the production of many different metals (oval rectangles) and the parent metal ores (cylinders) are displayed as a flowchart. This flowchart was used in the development of the COBALT sub-model in WORLD6. PGM platinum group metals

\section{Objectives and Scope}

Our goal was to use BRONZE, STEEL and PGM (platinum group metal) sub-models to be operated from inside the WORLD6 system dynamics model and add a cobalt submodule to the integrated structure. The objective is to use the WORLD6 model to explore what it would take to make the global cobalt supply system more sustainable.

\section{Earlier Work}

There have been several earlier attempts at modelling global cobalt extraction, cobalt demand and market supply rates. Some early predictions were made without any formalized simulation models, they represent educated guesses (Papp et al. 2008; Berger et al. 2011; Searle 2015; Dawkins et al. 2012; Willburn 2015). Roper (2014) used a fit to an empirical model analogous to the Hubbert's model. When applied to cobalt it becomes a non-linear curve-fitting to a curve where the integral of the curve fits the assumed extractable resource. The Hubbert's type of model used in singular mode is not applicable for cobalt because of cobalt's dependence on the extraction of other metals (Sverdrup and Ragnarsdottir 2014, 2015).

Mass flow analysis models have been used earlier for sustainability assessments for cobalt (Alonso et al. 2007; Alonso 2010; Halada et al. 2008; Gerst 2009; Elshakaki and Graedel 2013; Glöser et al. 2013a, b). As flow models are easy to use, but do have some shortcomings we need to be aware of. Mass flow analysis models do neither incorporate systemic feedbacks, nor do they have market dynamics and they cannot generate metal prices internally to the models. Most mass flow analysis models are linear in their fundamental function. Many of them are step-by-step mass balanced advanced 1 year at a time in spreadsheets (Gerst 2009; Mohr et al. 2014a, b).

We have in earlier studies developed system dynamic models for a number of metals: gold, silver, copper, rare earths, aluminium, iron, platinum group metals, lithium (Sverdrup et al. 2014a, b, 2015a, b, c; Sverdrup and Ragnarsdottir 2014; Sverdrup 2017; Sverdrup and Ragnarsdottir 2017), manganese, chromium and nickel as well as copper, zinc and lead metals with a number of associated minor metals and elements. In these integrated dynamic models, some of the major advances were the development of a reality-based metal price model, allowing for price estimation from market fundamentals inside the models, without external forcing functions or calibration. 
Table 2 shows an overview of cobalt demand for several current battery technologies. Limitations in cobalt supply may pose a problem for future production of rechargeable large batteries for electric vehicles, unless efficient substituting new technologies are developed. If we assume we will need one billion battery units in use in the future, then the cobalt column in Table 2 shows million ton cobalt required. The estimates can be seen to be in the range of from a very lowest estimate of 40 million ton cobalt (NiCD battery) up to as much as perhaps as much 470 million ton cobalt $\left(\mathrm{LiCoO}_{2}\right.$ battery). When the total supplied amount to the 2400 from land-based resources seems to be on the order of 32 million ton and ocean resources about the same, we will have a significant problem with making that many battery units. The situation is similar for nickel, from 84 million ton nickel up towards 500 million ton nickel would be required, when we have no more than maybe 250 million ton extractable nickel in total.

\section{Methods and Theory Used}

The methods used in this study are several. The reserves estimates are based on classical geological estimates from survey data, and the allocation of extractable amounts according to ore quality, stratified after extraction costs (Neumeyer 2000; Tilton and Lagos 2007; Tilton 2009, 2012; Boschen et al. 2013; Singer 2013; Wellmer 2008). Some complication is added when ocean seafloor resources are considered, but we have used the available literature for ocean resource estimates and the opportunity cost approach when it was included in the model. The main modelling method uses systems analysis and systems dynamics (Senge 1990; Sterman 2000; Sverdrup et al. 2014a, b, 2015a, b). Hubbert's model and burn-off rates were rejected for cobalt, as the production is dependent on other metals such as nickel, copper, chromium, platinum group metals as illustrated in Fig. 2. The basic methodology for the modelling work is based on systems analysis and systems dynamics.

\section{System Dynamics Modelling}

For the modelling work we use the standard methods of systems analysis and systems dynamics, making up causal links and flow pathways in the systems. System dynamics modelling methods were used to model the integrated system. We analyse the system using flowcharts based on box-arrow symbols, causal loop diagrams defining the mass balance expressed differential equations and they are numerically solved using the STELLA ${ }^{\circledR}$ systems dynamics methodology (Senge 1990; Sterman 2000; Sverdrup et al. 2014a, b, 2015a, b; Haraldsson and Sverdrup 2004). The model is based on mass balance expressed differential equations, and solved numerically. We use causal loop diagrams for reading to proposed policy interventions. The flow pathways and the causal chains and feedbacks loops in the system are mapped using systems analysis, and then the resulting coupled differential equations are transferred to computer codes for numerical solutions. The model is used to first reconstruct the past (1900-2015) to assess performance and robustness of the model. When the performance is satisfactory, then the model is used to simulate the possible future (2015-2400), having the support of being able to reconstruct the observed past pattern for 115 years.

\section{Defining Scarcity}

In this study we first assess cobalt scarcity and supply sustainability and then we need to define what scarcity really is in operational terms. Scarcity is defined as:

Table 2 Different battery types and their properties and materials requirements (adapted from Sverdrup 2017)

\begin{tabular}{|c|c|c|c|c|c|c|c|c|c|}
\hline \multirow[t]{2}{*}{ Components } & \multirow[t]{2}{*}{ Description of components and costs } & \multirow[t]{2}{*}{$\mathrm{Wh} / \mathrm{kg}$} & \multicolumn{6}{|c|}{$\begin{array}{l}500 \mathrm{~km} \text { range at } 190 \mathrm{Wh} / \mathrm{km} \text {, ingredient } \\
\text { weight, } \mathrm{kg}\end{array}$} & \multirow[t]{2}{*}{ Limiting metal } \\
\hline & & & $\mathrm{Li}$ & Co & $\mathrm{Ni}$ & $\mathrm{Mn}$ & REE & Battery & \\
\hline $\mathrm{LiCoO}_{2}$ & $\begin{array}{l}\text { The highest risk for self-ignition. Cathode material } \\
18 \$ / \mathrm{kg} \text {, cost of cathode } 27-36 \$ / \mathrm{kg}\end{array}$ & 170 & 56 & 476 & - & - & & -530 & Co \\
\hline \multirow{2}{*}{$\begin{array}{l}\mathrm{Li}\left(\mathrm{Co}_{\mathrm{n}} \mathrm{Ni}_{\mathrm{n}} \mathrm{Mn}_{\mathrm{n}}\right) \mathrm{O}_{2} \\
\mathrm{Li}\left(\mathrm{Co}_{\mathrm{v}} \mathrm{Ni}_{\mathrm{w}} \mathrm{Al}_{\mathrm{z}}\right) \mathrm{O}_{2} \\
(n=0.33, v=0.15 \\
\quad w=0.8, z=0.05)\end{array}$} & \multirow{2}{*}{$\begin{array}{l}\text { These batteries discharge and recharge faster. Cath- } \\
\text { ode material } 11 \$ / \mathrm{kg} \text {, cost of cathode } 22-30 \$ / \mathrm{kg}\end{array}$} & 150 & 25 & 63 & 84 & 66 & & -240 & $\mathrm{Co}, \mathrm{Ni}$ \\
\hline & & 150 & 25 & & 200 & - & & -240 & $\mathrm{Ni}$ \\
\hline $\mathrm{LiFePO}_{4}$ & Cathode material $1.5 \$ / \mathrm{kg}$, cost of cathode $20 \$ / \mathrm{kg}$ & 100 & 16 & 136 & - & - & & -152 & $\mathrm{Li}$ \\
\hline $\begin{array}{l}\mathrm{NiREEO}_{2} \\
\mathrm{La}_{0.8} \mathrm{Nd}_{0.2} \mathrm{Ni}_{2.5} \mathrm{Co}_{2.4}\end{array}$ & Complex mix of $\mathrm{Ni}, \mathrm{Co}$ and REE & $50-70$ & - & 350 & 400 & - & $50-300$ & 850 & REE, Ni, Co, Ni \\
\hline $\mathrm{NiCd}$ & Simple design. Toxic waste by failure & $40-60$ & - & 40 & 500 & - & & -1000 & $\mathrm{Cd}, \mathrm{Ni}, \mathrm{Ni}, \mathrm{Co}$ \\
\hline
\end{tabular}

REE rare earth elements. The table is adapted from Sverdrup (2017) 
- Soft scarcity where shipments into the market do not match the demand for delivery from the market, leading to an adjustment of price up, reducing demand and sometimes increasing the amount offered to the market. This down-sized demand is the sign of soft scarcity. The adjustment goes on until the offering into the market matches the demanded amount. The presently implemented open market economic mechanisms work well to handle soft scarcity. The previously considered command-and-control regimes did not cope well with scarcity, but had a tendency to worsen the situation.

- Hard scarcity has two variants:

- Economic scarcity where the demand is downsized by the increased price, but where the demand gets cut to zero by lack of ability to pay, while there is still material available (at high prices). If the use of the resource is a major bulk resource for society, then economic crisis will be the result if the resource is a keystone resource for the economy. Oil and coal are two such examples. If it is for a specialized but not essential technology, then failure of provision or and technical regression will be the result.

- Physical scarcity is where the supply cannot sufficiently cover the demand. There will be a demand gap, a difference between the adjusted demand and what really can be supplied. Even if money to pay whatever is asked, the material is not available. This is something that we have observed with platinum and rhodium from time to time in platinum metal trading. Failure of provision is the final result. Rhodium is an example where this has occurred on frequent occasions.

Scarcity can be offset by increasing supply into the market with increased recycling, or by reducing demands by substitution with other materials. Increasing recycling has both a price and a social component that will be addressed in later studies. Substitution is sometimes possible, but often not without issues of functionality. Scarcity is not a new phenomenon, but rather a standard component of economic systems. During the age of coal- and oil-driven economic growth, it may have appeared as if human society would have done away with scarcity of natural resources, as if we had succeeded in creating the limitless economy. However, from a perspective of economic history, and from human ecology and the principles of thermodynamics, a limitless society is nothing but an illusion, a naïve thought for the economically short-sighted. The past economic history was full of shortages and periods of economic contraction following economic growth as far as we can see (Meadows et al. 1972; Heinberg 2001). Thus, terms like "degrowth", "resource limitations" or "economic contraction" are neither revolutionary nor radical terms, but frequently reoccurring phenomena in human history where facts of history can be observed (Kennedy 1987; Diamond 1997, 2005). Over the last 2000 years, the economy of states and regions and empires have grown and shrunk in cycles in correlation with how their natural resources have been available (Kennedy 1987; Tainter 1990; Diamond 2005; Heinberg 2001). We are at the present time rapidly moving towards a world of limits again, challenging us to change our thinking and approaches (Ragnarsdottir and Sverdrup 2011; Sverdrup and Ragnarsdottir 2014). Models applied to policy assessment and policy development must be able to capture the whole cycle and those that can only handle increase in growth do not have much practical value.

\section{Basis for Estimating How Much Can be Extracted From Ore Deposits}

Table 3 shows the relationship between metal ore grade, production cost and minimum supply price to society, as well as impact of price on the recycling in market supply as
Table 3 General relationship between ore grade, the approximate production cost and minimum supply price to society, as well as impact of price on the recycling in market supply (adapted from
Sverdrup et al. 2015a, b and a large yet unpublished database by the authors for about 35 different metals and materials)

\begin{tabular}{|c|c|c|c|c|c|c|}
\hline \multirow[t]{2}{*}{ Ore grade } & \multicolumn{2}{|l|}{ Metal content } & \multirow[t]{2}{*}{ Extraction yield, $\%$} & \multirow[t]{2}{*}{ Extraction cost, $\$ / \mathrm{kg}$} & \multirow{2}{*}{$\begin{array}{l}\text { Market recy- } \\
\text { cling, } \%\end{array}$} & \multirow[t]{2}{*}{ Energy need, MJ/kg } \\
\hline & $\%$ & $\mathrm{~g} / \mathrm{ton}$ & & & & \\
\hline Rich & $40-5$ & & $100-99$ & $4-15$ & $0-30$ & 30 \\
\hline High & $5-1$ & & $99-98$ & $15-28$ & $30-40$ & $33-64$ \\
\hline Low & $1-0.2$ & $10,000-2000$ & $98-95$ & $28-50$ & $40-48$ & $120-160$ \\
\hline Ultralow & $0.2-0.04$ & $2000-400$ & $91-95$ & $50-100$ & $48-54$ & $400-600$ \\
\hline Extralow & $0.04-0.01$ & $400-100$ & $80-91$ & $100-160$ & $54-60$ & $700-1100$ \\
\hline Trace & $0.01-0.002$ & $100-20$ & $75-80$ & $160-400$ & $60-80$ & $3,000-20,000$ \\
\hline Rare & $>0.002-0.0004$ & $20-4$ & $55-75$ & $>400$ & $80-90$ & $>20,000$ \\
\hline
\end{tabular}

The values are illustrative of typical ranges 
we have used it in the model. The task is to divide the ultimately recoverable resources (URR) into known resources and hidden resources, graded into ore quality groups as we have displayed in Table 3. Hidden means that the resources exist, but must be found with prospecting before they are moved to "known" and can be mined. This classification we developed for copper, silver and gold initially, has subsequently been applied to all metals (Sverdrup 2017; Sverdrup et al. 2014a, b). This is the format needed for the submodels of the COBALT model system inside the WORLD6 model. The price range is based on data and the author's own professional experiences from copper, silver and gold extraction (Sverdrup et al. 2013, 2014a, b, but see also; Papp et al. 2008; Phillips and Edwards 1976), and does vary between ore types and metal types. The assessment was done by studying the available scientific literature, and a number of industrial reports and annual reports. All the estimates have then been added up in Table 3 (Wellmer 2008; Wellmer and Becker-Platen 2007; Tilton 2002; Sverdrup and Ragnarsdottir 2017). This assessment gives significantly larger estimates of the extractable amounts than conventional overview studies.

Cobalt systematically follows copper, nickel, chromium and platinum group metals in ore deposits (see Fig. 3). An important basis for the assessment is how much cobalt is available for extraction. We build on three different assessments based on two methods for the estimation. (1) The work of Mudd et al. (2013a, b) made an important assessment of the available amounts extractable of cobalt. (2) Harper et al. (2012) and (3) Eckstrand and Hulbert (2007) mapped where these deposits are located and of what origin they are, providing important geological background material. The USGS has renewed their resource assessment and updated it (Slack et al. 2010; Shedd 2015). The different estimates yield consistent results:

1. The estimation of extractable amounts of cobalt was done from copper, nickel, platinum group metal and cobalt production numbers. We ignored cobalt content in manganese and iron deposits, as cobalt is not extracted from these ores and the amounts of cobalt contained are limited. Our estimates are as follows:

a. Total global annual production of cobalt is 110,000 ton per year (USGS 2015). Originating from nickel, the cobalt extraction is 61,000 ton per year. Cobalt content in primary nickel extracted is $3-3.3 \%$. The extractable nickel known reserve is 73 million ton, the total known and hidden nickel resources have been approximated by the USGS as minimum 182 million ton. Analysing nickel resources in another ongoing study we find it is probably closer to about 300 million ton (Mohr et al. 2014a, see also in Table 4). In extractable nickel deposits there are 6-9 million ton cobalt (Nickless et al. 2014).

b. Annual production of copper is 17 million ton per year, the cobalt flow from copper is 39,000 ton per year. The cobalt content in the copper flow is on the average about $0.23-0.25 \%$ in the data available. If we estimate that the extractable copper amount is about 3700 million ton cop-

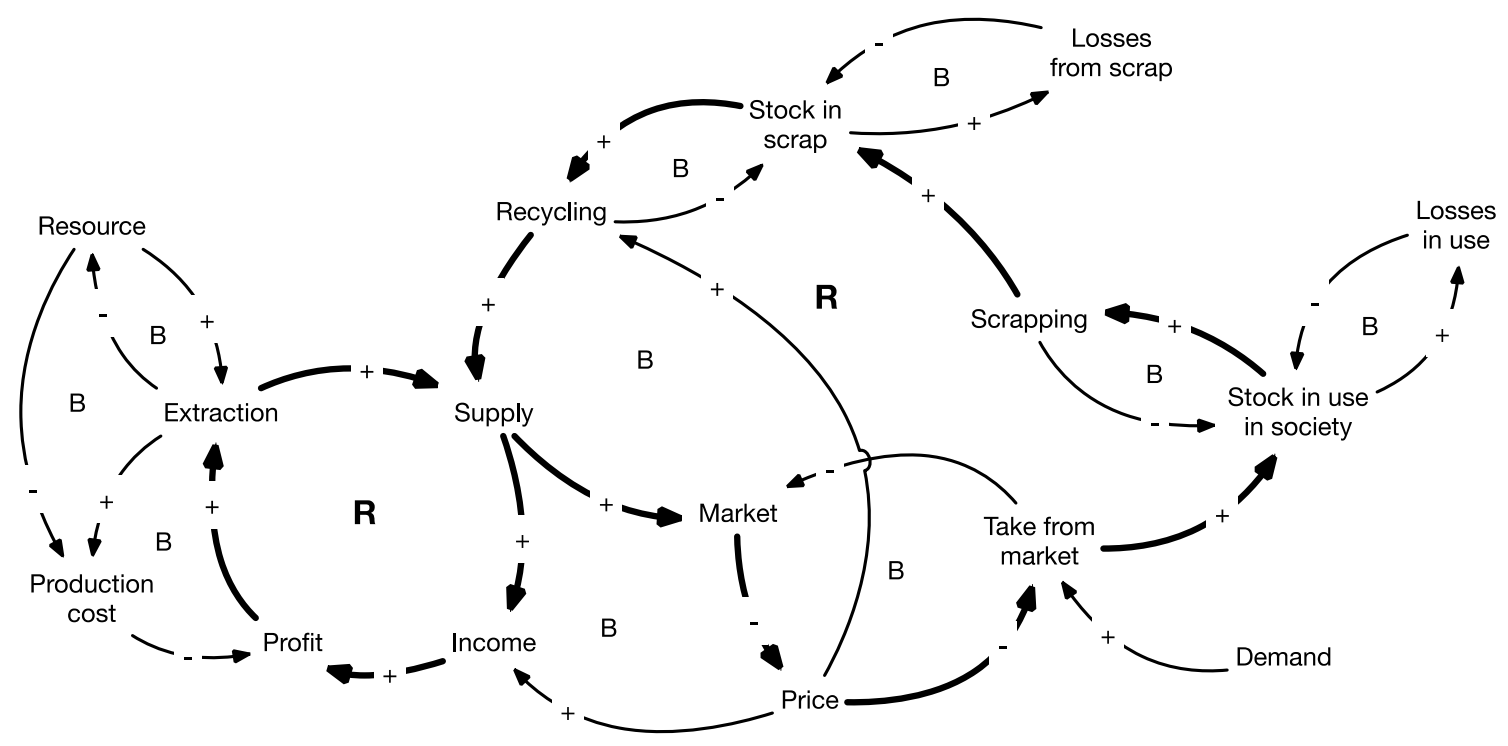

Fig. 3 The price mechanism as implemented in the COBALT submodel is shown as a causal loop diagram. The diagram shows how supply to the market, the market amount, price and take from market and demand are all connected into one system of mutual feedbacks. In the model this is used to calculate the price dynamically at each week. The time step in the model is 1 week 
Table 4 Sources of cobalt from secondary extraction and their concentration in the parent substrate, and estimate of total extractable amounts

\begin{tabular}{|c|c|c|c|c|c|c|}
\hline \multirow{2}{*}{$\begin{array}{l}\text { Parent source of cobalt } \\
\text { for extraction }\end{array}$} & \multicolumn{4}{|l|}{ This study } & \multirow[t]{2}{*}{ USGS (2015) } & \multirow[t]{2}{*}{ Mudd (2012) } \\
\hline & $\begin{array}{l}X_{i} \text { Parent material } \\
\text { Co content } \%\end{array}$ & $\begin{array}{l}\text { Average parent } \\
\text { metal resource }\end{array}$ & $\begin{array}{l}\text { Extractable amount, } \\
\text { million ton }\end{array}$ & $\begin{array}{l}\text { Included in the } \\
\text { model }\end{array}$ & & \\
\hline Copper & $0.23-0.3$ & 3767 & $6-11$ & Yes & 10 & $6-10$ \\
\hline Nickel & $3-3.3$ & 300 & $9-10$ & Yes & 9 & $9-10$ \\
\hline Chromium & $0.16-0.2$ & 2495 & $3-5$ & Yes & 2 & - \\
\hline PGM & 2000 & $0.2-0.3$ & $4-9$ & Yes & 2 & 1 \\
\hline Primary cobalt ores & $0.3-3.0$ & Not available & $0.5-2$ & No & 1 & 0.5 \\
\hline Old mine dumps & $0.2-0.7$ & 300 & $0.5-2$ & Yes & - & 0.5 \\
\hline Sums & & & $23-39$ & - & 20 & $22-29$ \\
\hline Extracted earlier & & & 3 & Yes & 3 & 3 \\
\hline URR on land & & & $26-41$ & - & 25.5 & $25-31$ \\
\hline Ocean floor deposits & $0.25-0.35$ & 2000 & $7-37^{a}$ & Yes & $148^{\mathrm{b}}$ & $5-7$ \\
\hline URR, land and ocean & & & $33-78$ & _- & n.a & $30-38$ \\
\hline
\end{tabular}

The content in the primary cobalt ore relates to rock cobalt content. All amounts are in million ton cobalt metal

${ }^{a}$ We have assumed that $1 / 4$ is technically extractable, but at considerable extra cost, see Table 6

${ }^{\mathrm{b}} \mathrm{No}$ assessment of extractability was done in that study

per (Henkens et al. 2014; Sverdrup et al. 2014b, $2015 b)$, then the extractable copper deposits contain about 8.5 million ton cobalt (8.5-9.3 million ton).

c. Other ores with cobalt are:

i. Cobalt production from PGM mining activity is about 10,000 ton/year, mostly in South Africa. The ores in South Africa are poly-metallic ores with copper, nickel, gold and platinum, where every metal contributes to the profitability of the extraction operation. Cobalt content in PGM ore is about 20 times the platinum content (40-100 g cobalt/ton rock, 0.4-1\%). This suggests that there is about 4-6 million ton cobalt in the extractable PGM deposits, about 200,000 ton PGM but maybe as much as 300,000 ton PGM, implying perhaps as much as 6-9 million ton cobalt.

ii. Chromium and manganese smelting and refining could yield maybe as much as 2000-3000 ton cobalt per year (assuming a content of about $0.16 \%$, or about 3-4 million ton). This much is not extracted at present, it would require a change in the chromium production technology in South Africa and other chromium- and manganese-producing nations.

iii. Extractable low-grade old mine dumps are estimated to contain about $0.3-0.5$ million ton cobalt (in South Africa and Peoples Republic of Congo, but also other places), but depending on $\mathrm{Ni}-\mathrm{Cu}-\mathrm{Co}$ content for economics of extraction. These are old dumps where older and less efficient extraction methods were used or where no attention was given to cobalt. This would be 0.5-1 million ton cobalt all together. d. In total this adds up to 23.3-32 million ton extractable cobalt. The historically extracted amount is somewhere between 2 and 3 million ton cobalt, this gives us URR $=26-35$ million ton.

2. USGS (2015) made an estimate in 2012 based on traditional assessment of reserves and resources, classifying them according to technical extractability and realityevaluated extractability. The results are as follows:

a. An estimate of 7.5 million ton for the cobalt reserve, and 13 million ton cobalt in the reserves base, total about 20.5 million ton cobalt in all (average content $0.36 \%$ ). Their justification for this estimate is available in the USGS website (Johnson et al. 2014; USGS 2015).

3. The Australian geologist Mudd et al. (2013a, b), Mudd and Jowitt (2014), at Monash University in Australia, made a new assessment by going through all known and recorded deposits, including the latest data, evaluated their extractability and came up with the following estimates:

a. 34 million ton recoverable cobalt, 16-20 million ton cobalt is estimated to be technically recoverable in: Nickel ores 5.5-6 million ton, poly-metallic ores with copper-zinc-lead, about 10 million ton cobalt, other ores of varying polymetallic compositions have an estimated content of about 0.5 million ton cobalt. Not included by Mudd et al. (2013a, b), Mudd and Jowitt (2014) were estimates of about 2000 million ton sub- 
sea ore with a cobalt content in the range $0.25-$ $0.35 \%$, translating to an approximate 5-7 million ton cobalt, bringing the total contained cobalt resources to about 32 million ton. These sub-sea deposits were concluded to be out of technical reach at present, and at present also too expensive to mine for their cobalt content. Excluded were also about 0.5 million ton cobalt in old mine waste dumps, which would be technically feasible resources to recover. In Mudd et al.'s (2013a, b) estimate, the implication is that $50 \%$ of detectable contained cobalt in deposits is extractable. His bottom line is that we have 16-17 million ton extractable out of about 34 million detectable.
In 2014, Mohr et al. (2014b) revised their nickel resources estimate to be at least 300 million ton extractable nickel. Our own recent estimates confirm this as the probable maximum amount for nickel URR. At a content of 3-3.2\% cobalt in the nickel that implies the content is about 9-10 million ton cobalt in such extractable resources, increasing the land-based URR to be in the range 32-36 million ton.

From the overview given in Table 4, we can see that there is consensus on the total land-based extractable amount to be in the range 30-38 million ton cobalt. Extraction of cobalt is energy intensive as can be seen from Table 5, which shows energy requirements for different steps. The
Table 5 Assessment of total production, reserves (Known) and technically extractable resources (Hidden) in million ton cobalt

\begin{tabular}{|c|c|c|c|c|c|}
\hline Country & $\begin{array}{l}\text { Extraction } \\
2015 \text {, ton/ } \\
\text { year }\end{array}$ & $\begin{array}{l}\text { Cobalt refining } \\
2015 \text {, ton/year }\end{array}$ & Deposit type or mother metal & $\begin{array}{l}\text { Reserves, } \\
\text { million } \\
\text { ton }\end{array}$ & $\begin{array}{l}\text { Resources, } \\
\text { million ton }\end{array}$ \\
\hline Congo DRC & 56,000 & 3300 & Copper & 3.400 & 14.5 \\
\hline China & 7200 & 42,000 & Copper, nickel, iron & 0.080 & 0.4 \\
\hline Canada & 7000 & 7000 & Copper, nickel, cobalt & 0.240 & 0.9 \\
\hline Australia & 6500 & 6500 & Copper, nickel & 1.200 & 4.5 \\
\hline Russia & 6300 & 2300 & Nickel, copper & 0.250 & 0.9 \\
\hline Cuba & 4200 & - & Nickel & 0.500 & 2.1 \\
\hline Phillipines & 3700 & - & Nickel & 0.500 & 1.2 \\
\hline Zambia & 3100 & 5300 & Copper & 0.270 & 1.2 \\
\hline South Africa & 3000 & 1400 & PGM, nickel, copper & 1.200 & 4.5 \\
\hline Brazil & 3000 & 1400 & Iron, copper & 0.890 & 2.1 \\
\hline New Caledonia & 3500 & - & Nickel & 0.370 & 0.9 \\
\hline Indonesia & - & - & Nickel & 0.080 & 1.0 \\
\hline Morocco & 1800 & 1800 & Cobalt ore & 0.020 & 0.2 \\
\hline Madagaskar & 2950 & 3000 & Copper & 0.500 & 1.5 \\
\hline France & - & 220 & - & - & - \\
\hline Belgium & - & 11,000 & - & - & - \\
\hline Finland & - & 11,400 & Nickel & 0.250 & 1.2 \\
\hline Norway & - & 4500 & Nickel & 0.050 & 0.5 \\
\hline Germany & - & 5000 & - & - & 0.2 \\
\hline Sweden & - & 2500 & Copper & 0.100 & 0.7 \\
\hline Japan & - & 3700 & - & - & - \\
\hline India & - & 1100 & Copper & - & 0.2 \\
\hline USA & 1260 & 5000 & Copper, nickel & 0.180 & 1.0 \\
\hline Other countries & 1750 & 2000 & Copper, nickel & 0.200 & 0.34 \\
\hline Cameroon & & & & 0.050 & 0.66 \\
\hline Sum & 110,000 & 118,200 & & 9.180 & 39.5 \\
\hline Recycling, waste & - & 12,000 & Metal waste, batteries & 2.200 & 2.5 \\
\hline URR & - & - & - & 11.380 & 43.7 \\
\hline Ocean floor & - & - & Crusts, nodules & 1.000 & $7-37.0^{\mathrm{a}}$ \\
\hline Global total & 110,000 & 129,200 & - & 12.280 & 80.7 \\
\hline
\end{tabular}

${ }^{a}$ As much as 148 million ton cobalt has been detected in deep-sea cobalt crusts and manganese nodules (Slack et al. 2010). If we assume that $25 \%$ is extractable, that corresponds to a resource of 37 million ton cobalt. That we probably should see as a high estimate (Smith and Heydon 2013, Hein et al. 2013). Mudd (2012) assumes that $5 \%$ of the ocean floor cobalt is technically extractable (7.5 million ton cobalt) 
COBALT module inside the WORLD6 model was run with the ultimately recoverable resources (URR), divided into quality classes as indicated in Table 3. Fundamental for this study is the estimation of how much metal can be extracted in total. This implies evaluation of how much metal is present, how much is technically extractable, disregarding price, energy or political obstacles. Both Mudd et al. (2013b) and (USGS 2015; Slack et al. 2010) include ocean seabed cobalt crusts, but they evaluated the crust cobalt content very differently.

The studies of the USGS are among the most valuable sources of information due to their wide scope, long term perspective and large degree of consistency (Shedd 2002, 2012, 2015; Papp et al. 2008; Slack et al. 2010; Berger et al. 2011; Newman 2011; Johnson et al. 2014; USGS 2015, 2014). The most recent USGS estimate is for cobalt detected in deposits, but with no serious assessment of extractability. There are a number of corporate prospects and pamphlets available on ocean seafloor mining, all very optimistic. However, these are aimed at potential investors and company shareholders, and may not represent the most down-to-Earth assessments. Ocean floor mining technology is currently being developed, much supported by advances in deep-sea oil exploration. However, such undertakings appear as technologically challenging and as capital intensive (Allsopp et al. 2013; Clark and Smith 2013a, b). Mudd et al. (2013b) estimates that a lot of cobalt is present, but very little is technically extractable.
A list of production rates and estimated resources are shown in Table 5. The main cobalt-producing country is the Peoples Republic of Congo, in Africa. They produce one-third of the global output (about 56,000 ton per year). The production in these countries is associated with copper production. They are followed by a number of countries in the range from 8000 to 3000 ton per year. The assessment was done by going through the available scientific literature and a number of industrial reports and annual reports, independent from the sources behind the information in Table 4.

All the estimates have then been added up in Table 5 . This assessment gives significantly larger estimates of the extractable amounts than conventional overview studies like those of the USGS. Table 6 shows the resources of cobalt from secondary extraction and their concentration in the parent substrate, and estimate of total extractable amounts. The content in the primary cobalt ore relates to rock cobalt content. Table 7 shows an overview of deepsea metal resources. The extractability estimates rely on a number of scientific studies (Tilton 1983; Herzig and Hannington 1995; Clark et al. 2005, 2010, 2013; Beckmann 2007; Zhou 2007; Hein et al. 2009, 2010, 2013; Hoagland et al. 2009; Roberts 2012; Boschen et al. 2013; Mudd 2012; Muiños et al. 2013; Smith and Heydon 2013; Cailteaux et al. 2005; International Seabed Authority 2015; Beaudoin et al. 2014; Johnson et al. 2014; Schmidt 2015) and this study. Table 8 shows the relationship between cobalt
Table 6 Sources of cobalt from secondary extraction and their concentration in the parent substrate, and estimate of total extractable amounts

\begin{tabular}{|c|c|c|c|c|c|}
\hline \multirow{2}{*}{$\begin{array}{l}\text { Parent source of } \\
\text { cobalt for extrac- } \\
\text { tion }\end{array}$} & \multirow{2}{*}{$\begin{array}{l}\text { Parent metal } \\
\text { resource, million } \\
\text { ton }\end{array}$} & \multirow{2}{*}{$\begin{array}{l}\text { Cobalt content in } \\
\text { mother material, \% } \\
\text { Medium }\end{array}$} & \multirow[t]{2}{*}{$\begin{array}{l}\text { Fraction of mines with } \\
\text { Co extraction capability }\end{array}$} & \multicolumn{2}{|c|}{$\begin{array}{l}\text { URR, million } \\
\text { ton }\end{array}$} \\
\hline & & & & Standard & High \\
\hline Copper & 3767 & 0.23 & Variable; $0-0.8$ & 8 & 16 \\
\hline Nickel & 300 & 3.2 & Variable; $0.2-0.7$ & 10 & 14 \\
\hline Chromium & 2495 & 0.12 & Variable; 0-0.5 & 2 & 4 \\
\hline PGM & 0.3 & 2000 & 1.0 & 3 & 6 \\
\hline Primary ores & 100 & 1.0 & 1.0 & 2 & 5 \\
\hline Ocean floor & 148 & 4.7 & 1.0 & 7 & 37 \\
\hline URR & - & - & & 32 & 82 \\
\hline
\end{tabular}

The content in the primary cobalt ore relates to rock cobalt content. All amounts are in million ton cobalt metal
Table 7 Overview of deep-sea metal resources

\begin{tabular}{lrlcll}
\hline Type & Depth, $\mathrm{m}$ & Metals & $\begin{array}{l}\text { Co content, } \\
\text { mill ton }\end{array}$ & $\begin{array}{l}\text { Extractable } \\
\text { fraction, } \%\end{array}$ & $\begin{array}{l}\text { Co extract- } \\
\text { able, mill } \\
\text { ton }\end{array}$ \\
\hline Manganese nodules & $4000-6000$ & $\mathrm{Ni}, \mathrm{Cu}, \mathrm{Co}, \mathrm{Mn}$ & 38 & $5-25$ & $1.9-9.5$ \\
Cobalt crusts & $800-2500$ & $\mathrm{Co}, \mathrm{V}, \mathrm{Mo}, \mathrm{Pt}$ & 110 & $5-25$ & $5.5-27.5$ \\
Sulphide deposits & $1400-3700$ & $\mathrm{Cu}, \mathrm{Pb}, \mathrm{Zn}, \mathrm{Au}, \mathrm{Ag}$ & 2 & $5-25$ & $0.1-0.5$ \\
Sums & & & & & $7.5-36.5$ \\
\hline
\end{tabular}


Table 8 Relationship between sea floor copper ore grade, production cost and URR

\begin{tabular}{lcclcl}
\hline Grade & Ore metal content, $\%$ & \multirow{2}{*}{$\begin{array}{l}\text { Extraction } \\
\text { cost, } \$ / \mathrm{kg}\end{array}$} & & \multicolumn{2}{l}{ Million ton cobalt } \\
\cline { 5 - 6 } & & & Hidden & Known & Sum \\
\hline Sea floor grade low & $1-0.2$ & 50,000 & 2 & 1 & 3 \\
Sea floor grade ultralow & $0.2-0.04$ & 80,000 & 4 & 0 & 4 \\
Sum & & & 6 & 0 & 7 \\
\hline
\end{tabular}

ore grade, the approximate production cost and minimum supply price to society, for a high and a low case for recoverability.

The size of the cobalt resource is dependent on the estimates for the total copper and nickel resources. Thus, the total extractable resource estimates for these metals must be discussed. Johnson et al. (2014) attempt to estimate the copper resources around the world, stating that in addition to identified 2100 million ton, they suggest that about 3500 million ton copper resources should exist, making a total copper resource of 5600 million ton (URR). They considered porphyry copper deposits down to $1 \mathrm{~km}$ depth and sediments and strata-bound copper down to $2.5 \mathrm{~km}$ depth. However, the copper ore grade distribution in the resource and extractability remain unknown, and the proposed additional 3500 million ton copper cannot be added to the known resources of 2100 million ton copper without a proper extractability assessment. Such an assessment of extractability has not been undertaken. Assuming that $1 / 3-1 / 2$ of the resources given by Johnson et al. (2014) are in reality extractable, then the total URR for copper would be in the order of 3270-3850 million ton copper.

Additional information concerning mining technologies and technical development was taken from Rosenqvist (1949), Allen and Behamanesh (1994), Liessmann (1994), Hawkins (2001), Wagner and Fettweis (2001), Shedd (2002, 2012, 2015), Alonso et al. (2007), Papp et al. (2008), Berger et al. (2011), Boliden (2011), Cobalt Facts (2011), Newman (2011), Harper et al. (2012), Wübbeke (2012), Walther (2014), Dawkins et al. (2012), Searle (2015), Spencer and Searle 2015, Willburn (2015), Rasilainen et al. (2010a, b, 2012), Alonso (2010), Berry (2015), Brown et al. (2015), Cailteaux et al. (2005), Cobalt/Investing News (2014), Crowson (2011), Dalvi et al. (2004), Dawkins et al. (2012), Hagelüken and Meskers (2009), Hannis and Bide (2009), Idaho Cobalt Mine (2015), Kesler and Wilkinson (2013a, b), Martino and Parson (2011), Nuss and Eckelmann (2014). The extractable amounts were set at the beginning of the COBALT model simulation in 1900 , stratified with respect to ore metal content and relative extraction cost based on yield of extraction and energy requirements. All major model inputs on resources were extracted from earlier published information.

Harmsen et al. (2013) and Henckens et al. (2014) use an estimate for the total extractable nickel resource at
1800 million ton, but we can find no scientific support for such a large estimate in the available scientific literature (Mudd et al. 2013b; Mudd and Jowitt 2014). With no scientific basis in numbers, it would appear to be a wild guess. Johnson et al. (2014) agrees with this, and states that the copper resource estimates in Harmsen et al. (2013) and Henckens et al. (2014) are not suitable for any sufficiency assessments. We have done an extensive survey of the literature and found that there is more nickel available than what the traditional estimates suggests by about a factor of two. This is shown in Table 4, where we estimate the nickel resources to be at least 183 million ton and more probably about 300 million ton (Mudd and Jowitt 2014). The full assessment of global nickel resources will be published in a separate study. Table 9 shows the relationship between primary hard rock copper ore grade, the approximate production cost and minimum supply price to society, and URR used in the COBALT model. This is a minor part of the URR for cobalt $\left(\mathrm{URR}_{\text {Mines }}=2\right.$ million ton). Table 10 shows an overview of the input data to the COBALT submodel fin WORLD6 or extractable amounts at the starting time for the simulations. Both land-based and ocean sea-floor resources were included. The ocean seafloor extractable resources are five times those of Mudd (2012), assuming $25 \%$ extractability.

\section{Model description}

\section{Structural description}

The COBALT submodel is a model arrangement inside the WORLD6 model consisting of a system of sub-models. Figures 4 and 5 show the connection between the

Table 9 Relationship between primary hard rock copper ore grade, the approximate production cost and minimum supply price to society, and URR used in the model

\begin{tabular}{lcllll}
\hline Grade & \multirow{2}{*}{$\begin{array}{l}\text { Ore metal content, } \\
\%\end{array}$} & $\begin{array}{l}\text { Extraction } \\
\text { cost, } \$ / \\
\text { ton }\end{array}$ & \multicolumn{2}{l}{ Million ton cobalt } \\
\cline { 4 - 6 } & & 28,000 & 0.290 & 0.010 & 0.300 \\
\hline Low & $1-0.2$ & 50,000 & 1.000 & 0 & 1.000 \\
Ultralow & $0.2-0.04$ & 80,000 & 0.700 & 0 & 0.700 \\
Trace & $0.04-0.01$ & & 1.990 & 0.010 & 2.000 \\
Sum & & & & &
\end{tabular}


Table 10 Input data to the model for extractable amounts, at the starting time for the simulations

\begin{tabular}{|c|c|c|c|c|c|}
\hline \multicolumn{6}{|c|}{ Secondary extraction } \\
\hline \multirow[t]{2}{*}{ Ore grade } & \multicolumn{3}{|c|}{ Million ton copper } & \multirow[t]{2}{*}{ Ore grade $\mathrm{Cu}, \%$} & \multirow[t]{2}{*}{$\mathrm{kg} \mathrm{Cu}$ per ton rock } \\
\hline & Known & Hidden & Sum & & \\
\hline Rich & 15 & 5 & 20 & $40-5$ & $400-50$ \\
\hline High & 10 & 20 & 30 & $5-1$ & $50-10$ \\
\hline Low & 100 & 1250 & 1350 & $1-0.2$ & $10-2$ \\
\hline Ultralow & 15 & 1200 & 1215 & $0.2-0.04$ & $2-0.4$ \\
\hline Extralow & 15 & 1100 & 1115 & $0.04-0.01$ & $0.4-0.1$ \\
\hline Sums & 155 & 3575 & 3730 & & \\
\hline \multirow[t]{2}{*}{ Ore grade } & \multicolumn{3}{|c|}{ Million ton nickel } & \multirow[t]{2}{*}{ Ore grade $\mathrm{Ni}, \%$} & \multirow[t]{2}{*}{$\mathrm{kg} \mathrm{Ni}$ per ton rock } \\
\hline & Known & Hidden & Sum & & \\
\hline High & 29 & 1 & 30 & $5-1$ & $50-10$ \\
\hline Low & 6 & 36 & 42 & $1-0.2$ & $10-2$ \\
\hline Ultralow & 3 & 110 & 113 & $0.2-0.04$ & $2-0.4$ \\
\hline Sum & 38 & 147 & 185 & & \\
\hline \multirow[t]{2}{*}{ Ore grade } & \multicolumn{3}{|c|}{ Ton platinum group metals } & \multirow[t]{2}{*}{ Ore grade PGM, \% } & \multirow{2}{*}{$\begin{array}{l}\text { g PGM per ton } \\
\text { rock }\end{array}$} \\
\hline & Known & Hidden & Sum & & \\
\hline Extralow & 2000 & 38,000 & 40,000 & $0.01-0.005$ & $10-5$ \\
\hline Trace & 0 & 47,000 & 47,000 & $0.005-0.002$ & $5-2$ \\
\hline Rare & 0 & 64,000 & 64,000 & $0.002-0.0004$ & $2-0.4$ \\
\hline Nickel ore & 5000 & 18,000 & 23,000 & & $5-0.5$ \\
\hline Sums & & & 174,000 & & \\
\hline \multirow[t]{2}{*}{ Ore grade } & \multicolumn{3}{|c|}{ Million ton chromium } & \multirow[t]{2}{*}{ Ore grade $\mathrm{Cr}, \%$} & \multirow[t]{2}{*}{$\mathrm{kg} \mathrm{Cr}$ per ton rock } \\
\hline & Known & Hidden & Sum & & \\
\hline Rich & 50 & 700 & 750 & $55-5$ & $550-50$ \\
\hline High & 0 & 800 & 800 & $11-2$ & $110-20$ \\
\hline Low & 0 & 1000 & 1000 & $2-0.5$ & $20-5$ \\
\hline$\underline{\text { Sums }}$ & 50 & 2450 & 2500 & & \\
\hline \multicolumn{6}{|c|}{ Primary cobalt mining } \\
\hline \multirow[t]{2}{*}{ Ore grade } & \multicolumn{3}{|c|}{ Million ton cobalt } & \multirow[t]{2}{*}{ Ore grade Co, $\%$} & \multirow[t]{2}{*}{$\mathrm{kg}$ Co per ton rock } \\
\hline & Known & Hidden & Sum & & \\
\hline Low & 0.01 & 0.290 & 0.300 & $1-0.5$ & $10-5$ \\
\hline Ultralow & 0 & 1.000 & 1.000 & $0.5-0.1$ & $5-1$ \\
\hline Extralow & 0 & 0.700 & 0.700 & $<0.1$ & $<1$ \\
\hline Sums & 0.010 & 1.990 & 2.000 & & \\
\hline
\end{tabular}

Ocean seabed primary cobalt mining

\begin{tabular}{llllll}
\hline Ore grade & \multicolumn{2}{l}{ Million ton cobalt } & & Ore grade Co, \% & kg Co per ton rock \\
\cline { 2 - 4 } & Known & Hidden & Sum & $1-0.2$ & $10-2$ \\
\hline Low & 1 & 20 & 21 & $<0.2$ & $<2$ \\
Ultralow & 1 & 14 & 15 & & \\
Sums & 2 & 34 & 36 & \\
\hline
\end{tabular}

Both land-based (primary and secondary) and ocean sea-floor resources were included 


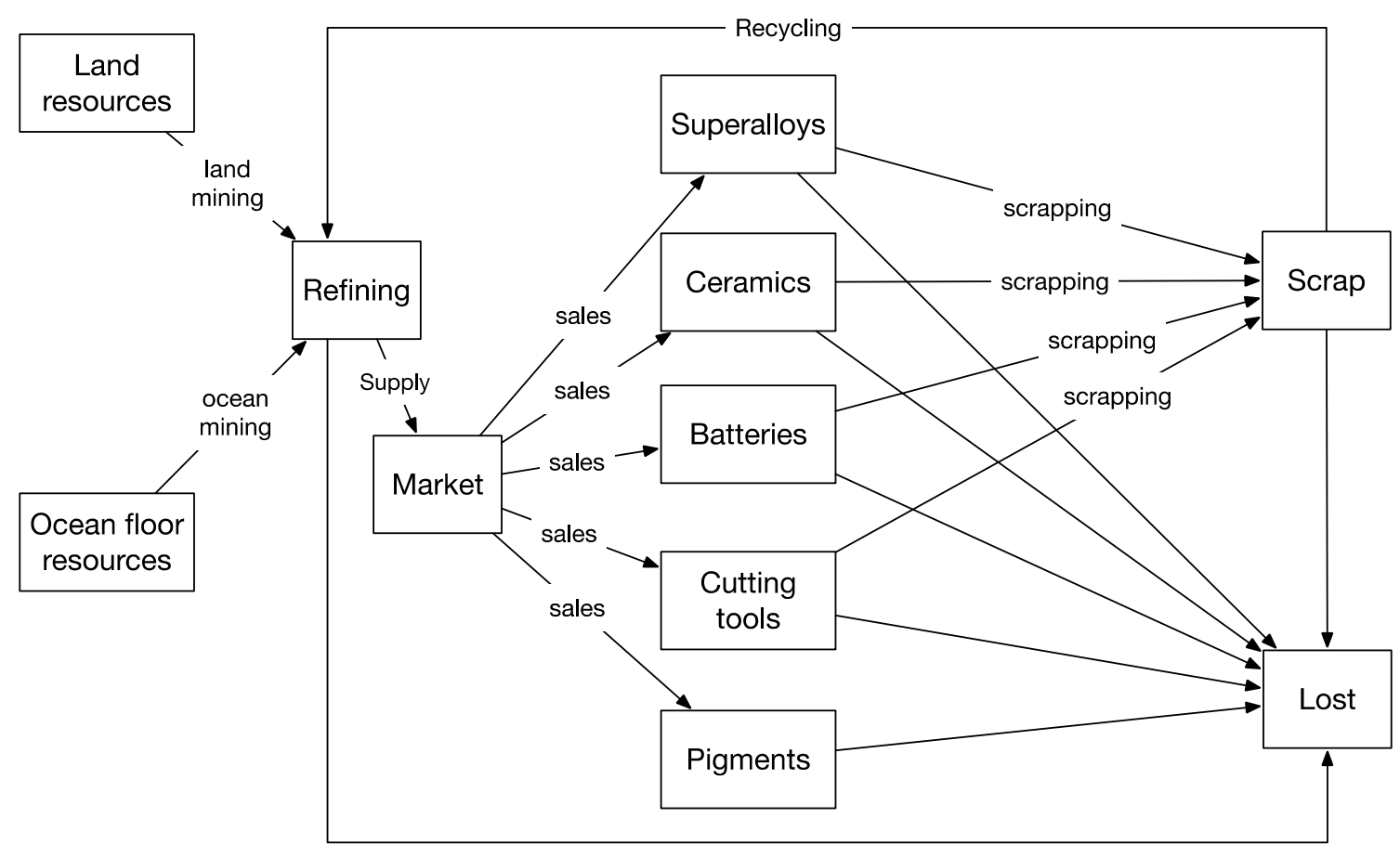

Fig. 4 Flowchart for cobalt flow in society as pictured in the COBALT submodule in WORLD6. This is continued in Fig. 5 and reflected in the STELLA structure shown in Figs. 6 and 7

production of many different metals and the parent metal ores displayed as a flowchart. The COBALT submodel consists of the following parts based on earlier models (Sverdrup et al. 2014a, b) and new system dynamics parts (Sverdrup et al. 2015a, b, c; Sverdrup and Ragnarsdottir 2017) as shown in Fig. 5:

1. BRONZE submodel for, zinc, lead and many dependent metals (silver, antimony, bismuth, indium, gallium, germanium, tellurium, selenium, cadmium), including the COPPER and SILVER submodels (Sverdrup et al. 2014a, b)

2. STEEL sub-model for iron, manganese, chromium and nickel, including the IRON submodel.

3. PGM submodel for platinum, palladium and rhodium, in conjunction with the STEEL submodel.

4. A submodel for the simulation of primary mining of cobalt.

5. Inside the COBALT submodel is a newly developed sub-module for the cobalt market cycle.

Figure 3 shows the causal loop diagram defining the market dynamics in the model, where the price is an output from market mechanisms involving supply to the market, supply to customers from the market in response to demand. Note that supply from the market is not necessarily the same as the demand. Figure 6 shows the STELLA diagram for the whole COBALT submodel.

All of this is embedded into the WORLD6 model, and the COBALT submodel is operated and run from within the WORLD6 model. The simulation of the primary mining of copper, zinc, lead and antimony and silver are in their own modules, the dependent metals are calculated from the production of these primary metals. Recycling from society and waste dumps provides a substantial flow of copper in comparison with rock mining. The COBALT submodel is numerically integrated using a 0.02-year time-step in a 4-step Runge-Kutta numerical method of integration in the STELLA $®$ modelling software (Fig. 6). That means we have values every week. Table 5 shows the input data for extractable amounts used to initiate the COBALT submodel. The main extractable amounts of cobalt are associated with nickel, copper and platinum group metals deposits.

The full causal loop diagram for metal mining and copper in particular has been published earlier (Sverdrup et al. 2014a, b, 2015a, b). Population estimates from the WORLD6 model are used in the demand estimates (Ragnarsdottir et al. 2012) (see Fig. 9). 


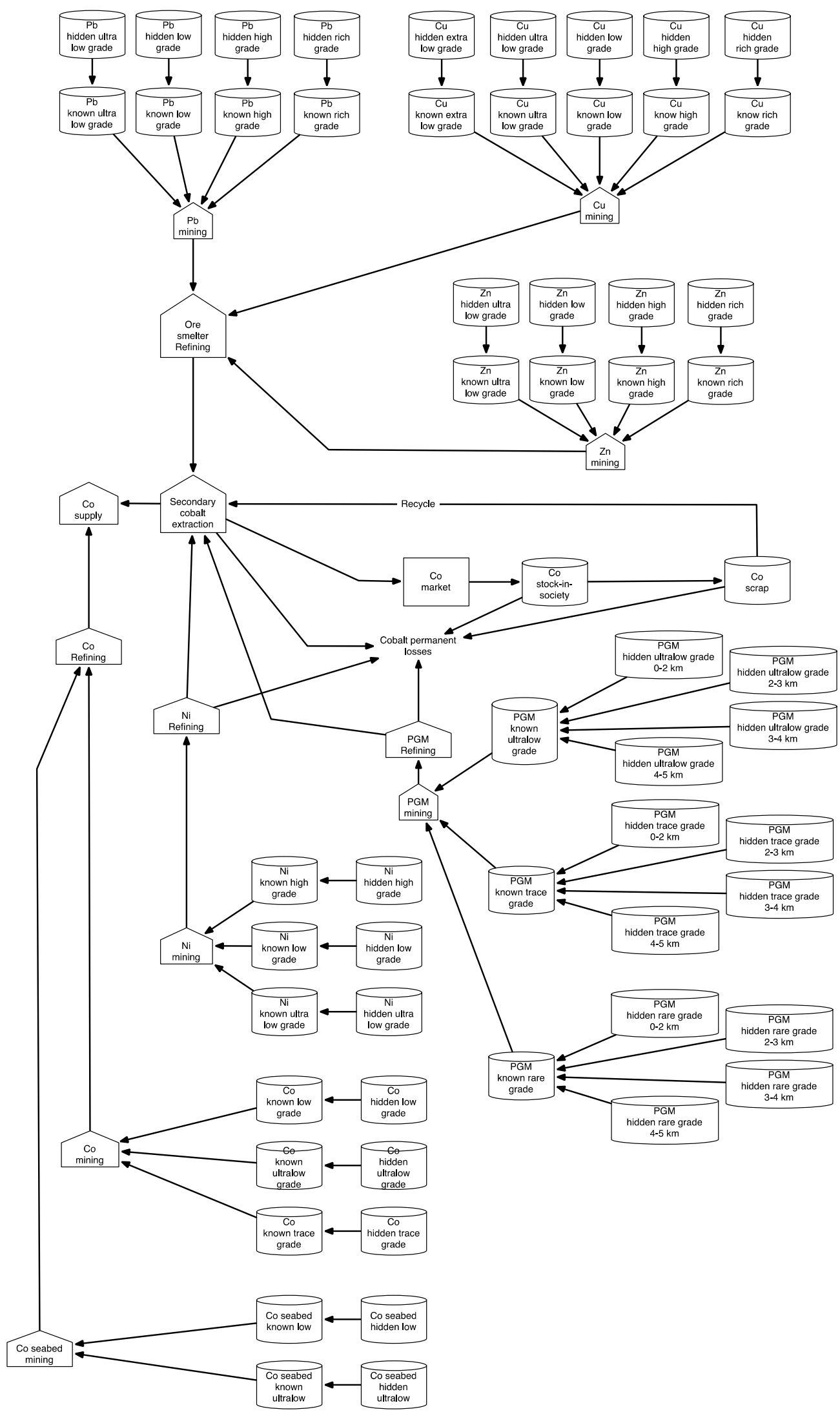

Fig. 5 Flowchart for the COBALT submodel, including independent and dependent metals relevant to cobalt. The stocks sorted up into extraction cost classes are shown. The COBALT submodel is embedded into the WORLD6 model (see Fig. 13) 


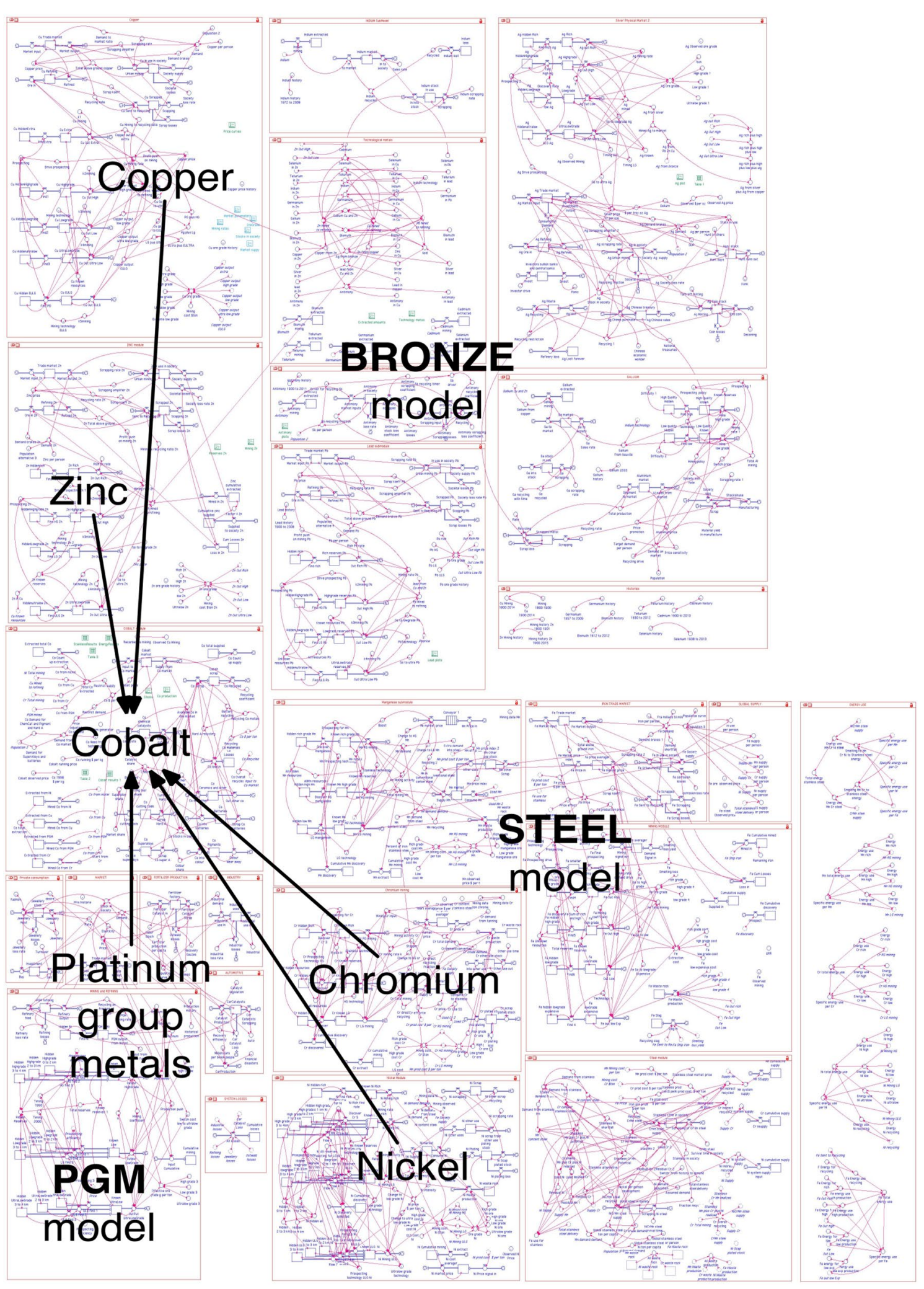

Fig. 6 The STELLA diagram for the whole COBALT submodel including the linked systems dynamics submodels BRONZE, STEEL and PGM that we have developed earlier as a part of the WORLD6 model system. The submodels ALUMINIUM (Sverdrup et al. 2015a) and SILVER (Sverdrup et al. 2014a, b) are found as sub-modules inside the BRONZE model, the IRON sub-module (Sverdrup et al. 2016c) is found inside the STEEL submodel. All of this is embedded into the WORLD 6 model (See Fig. 13) 


\section{Rate Equations and Feedback Functions}

The rate of cobalt primary production is determined by the following equation:

$r_{\text {Cobalt }}=r_{\mathrm{Ni}} \times X_{\mathrm{Ni}}+r_{\mathrm{Cu}} \times X_{\mathrm{Cu}}+r_{\mathrm{PGM}} \times X_{\mathrm{PGM}}+r_{C r} \times X_{C r}$

where $r_{\text {cobalt }}$ is the rate of cobalt extraction in million ton metal per year, $r_{\mathrm{Ni}}$ the contribution from secondary extraction of cobalt from nickel production, $r_{\mathrm{Cu}}$ is cobalt from copper production, $r_{\mathrm{Cr}}$ is cobalt from chromium production and $r_{\mathrm{PGM}}$ is cobalt from platinum group metals production. The values of the different $X_{i}$ are given in Table 3 , it is a unitless fraction. The extraction is firstorder proportional to the amount of substrate from the primary mother metals treated in refining. In addition to this, the general mass balance principle applies with all inputs being balanced by the outputs and the accumulation in society:

Prod + Recycl $=\frac{\mathrm{dm}}{\mathrm{dt}}+$ loss + recycl

Note that recycling is present on both sides, helping to hold a large amount inside the loop. Recycling is present on both sides, and this is how recycling helps keep the flow through society up even when primary production declines (Fig. 8a). For metal recycling we used the following equation (adapted after Sverdrup et al. 2014a, b):

$R=0.3 \times \log _{10}($ Price $)+f$ (policy)

for the applied feedback function for recycled fraction. $R$ is the recycled fraction of the total supply, $P$ is the price in US dollars per $\mathrm{kg}$ and $f$ (policy) is a unitless function depending on regulations and social training of the agents in the market. With social training we mean ways to have the consumers and actors have recycling and a more inherent behaviour, independently of monetary drivers. In the model, market price is determined by the amount present as tradable in the market. The market price curve for cobalt is derived from Fig. 7b where we have plotted market inventories against the observed global market price for cobalt. The equation is in US dollars per ton:

Cobalt price $=\left(21,867 \times\right.$ Market stock $\left.^{-0.57}-20\right) \times g(E)$

$g(E)$ is the market efficiency, a unitless scaling function that varies with time. It has the value 0.5 until about 1960 , and then increases to 1 by 1980 , when the metal trade markets became organized and much more efficient, especially for cobalt. The correlation to the observed points between market stock and cobalt price is $r^{2}=0.99$ (Fig. 8a). The more material in the market, the lower the price. The amount of cobalt in the market depends on both the speed of delivery (supply) and the shipping from the market (demand). The cobalt amount taken from the market $(F)$, as promoted by demand, was calculated as follows:

$\left.F=\left[D_{\mathrm{NM}} \times P \times\left(1-Z_{\mathrm{M}}\right)+D_{\mathrm{NM}} \times Z_{\mathrm{M}}\right)\right] \times f(D) \times g(S)$

$F$ is the amount cobalt that is taken from the market. $D_{\mathrm{NM}}$ is the specific cobalt demand per person. This amount is limited by what is available, where $Z_{\mathrm{M}}$ is the fraction metallic cobalt in the demand. This demand was assumed to be higher for metals than for non-metallic uses. The factors $D_{\mathrm{NM}}=0.00166$ and $D_{\mathrm{M}}=0.00332$ imply a demand of $1.66 \mathrm{~g}$ cobalt per person for non-metallic uses and $3.32 \mathrm{~g}$ cobalt per person for metallic uses. $f(D)$ is the unitless feedback function limiting demand with higher price and $g(S)$ is technological development, a unitless scaling factor. $P$ is the global population in billion people taken from the population module in WORLD6. The actual rate of cobalt extraction is maximized by the rate of extraction of nickel, copper and PGMs, the parent substrates it is contained in.

Figures 8, 9, 10, 11, 12 and 13 show some of the feedback functions from the model that we use in the COBALT submodel. Figure 8a shows the empirically determined price curve for cobalt as a function of London Metal Exchange market stock. Figure $8 \mathrm{~b}$ shows the applied feedback function for the fraction recycled materials as a function of the price, in US dollars, value-adjusted to 1998. The higher the market price, the more recycling efforts will be stimulated. Figure 10a shows the fraction of supply as recycled, a function of metal price. It shows how much market mechanisms make recycling as a \% fraction of supply increase when the metal price goes up. Adapted with data from Lenzen (2008), Prior et al. (2012, 2013) and Dahmus and Gutowski (2007) for Sverdrup et al. (2014a, b). The diagram was used to parameterize Eq. (3). Figure 10a shows the applied price feedback function for the restriction on demand. The higher the price, the lower the demand. Figure 10b shows the applied feedback function for the restriction on supply. For the feedback, a one-andhalf year running average is used. This running average is adapted, because society is not instantaneous in its response to change in the market price. Figure 10c shows the applied feedback function for the fraction recycled materials as a function of price. Figure 9 shows the population curve from the World3 sub-module and the alternative United Nations forecast for populations with no resource feedbacks of any kind. The World 3 model simulation peak in 2040 at 8.6 billion people, the WORLD6 simulation peak at 9.1 billion people in 2045 and the UN forecast in 2065 at 9.8 billion people. We use the global population from the population model inside the WORLD6 to estimate the global cobalt demand from the per capita estimation (Fig. 11a). We use the predictions internal to the WORLD6 model, as well as the United Nations populations predictions which are 


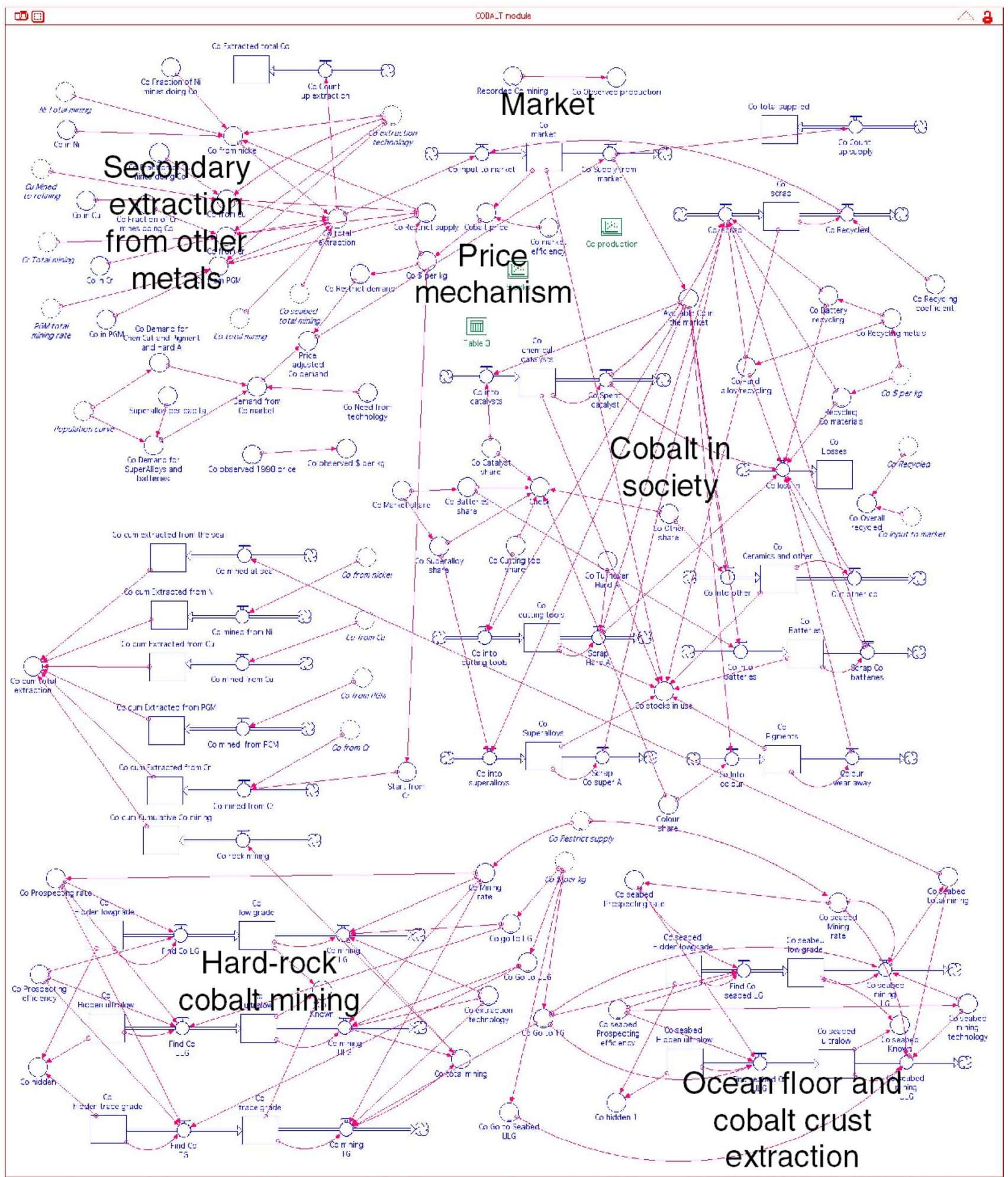

Fig. 7 The cobalt sub-module of the WORLD6 model as shown in Figs. 4 and 5, implemented inside the STELLA software shown in Fig. 6 The titles overwritten on the diagram shows the different modules for secondary extraction, using copper, nickel, chromium and platinum group metals as input. In the model is also included hard rock mining in Canada and Morocco and future ocean seabed mining. Figure 3 shows the causal loop diagram implemented in this module 
Fig. 8 a The price curve found for cobalt, by plotting market tradable inventory against observed price. The red line is the fitted equation. b The actual curve modified from $\mathbf{a}$ and entered in the model as Eq. (4). Curve b comes down a bit faster at higher market contents than the fit to data in a. The curves are derived from the private metal trading archives of one of us (Sverdrup) and are in the process of being published

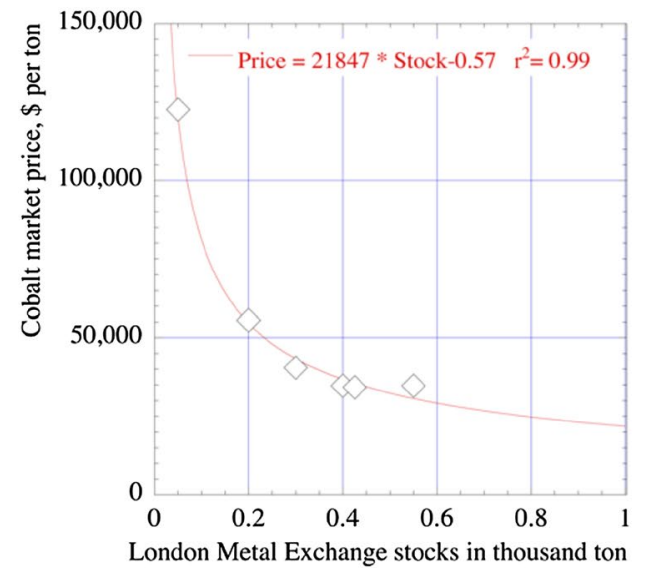

a

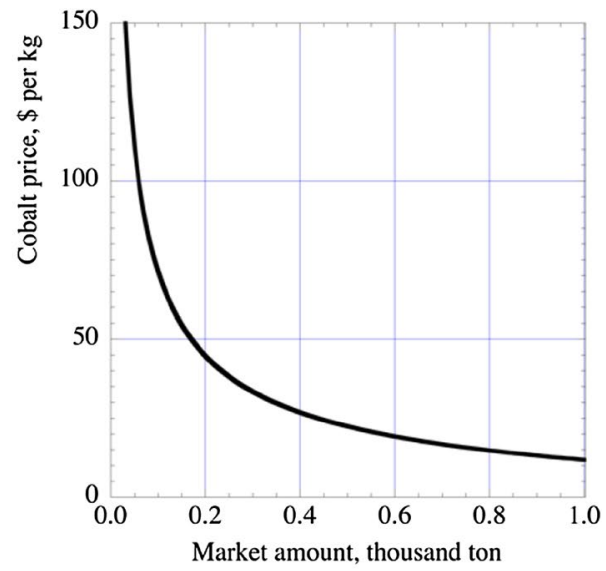

b

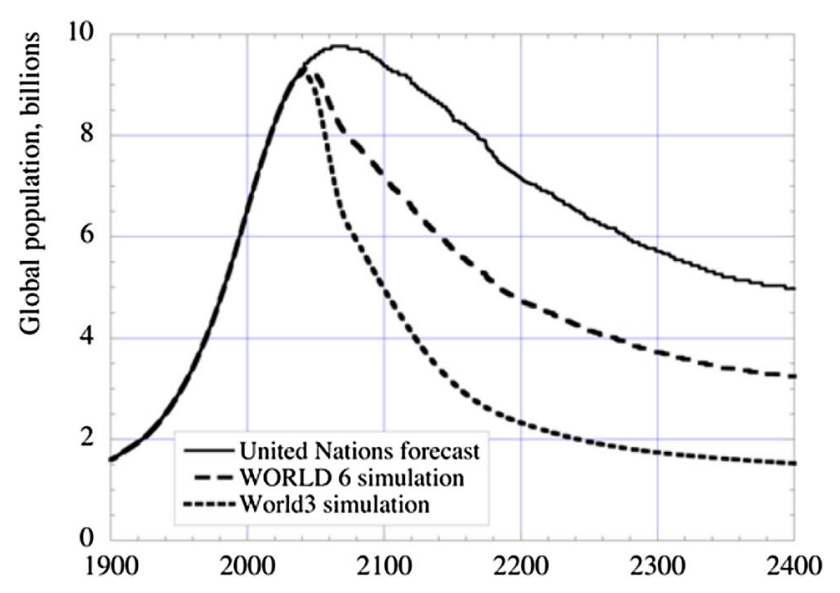

Fig. 9 The population curve coming from World3 model, (W3 scenario), the new population estimates from WORLD 6 (W6 scenario) and the alternative United Nations forecast for populations with no resource feedbacks of any kind (UN scenario) politically correct, but probably flawed (Meadows et al. 2005; Greer 2008).

Figure 11a shows the applied increase in demand from the technological development of new industrial cobalt uses. The fluctuations reflect the instability of production caused by problems in unstable countries in Central Africa. Prices are in American inflation adjusted dollar value with 1998 as the reference year. The main market model used for cobalt is the same as used in our earlier models (Sverdrup et al. 2013, 2014a, b, 2015a). Figure 11b shows the efficiency of the cobalt extraction technology and methods and Fig. 11c shows the applied restriction on hard rock cobalt mining and ocean mining from price feedbacks.

Figure 12 shows the share of total cobalt supply going to super-alloys and batteries. The demand for cobalt to batteries comes from the battery module in the lithium submodule of the WORLD6 model (see Fig. 13 for details).

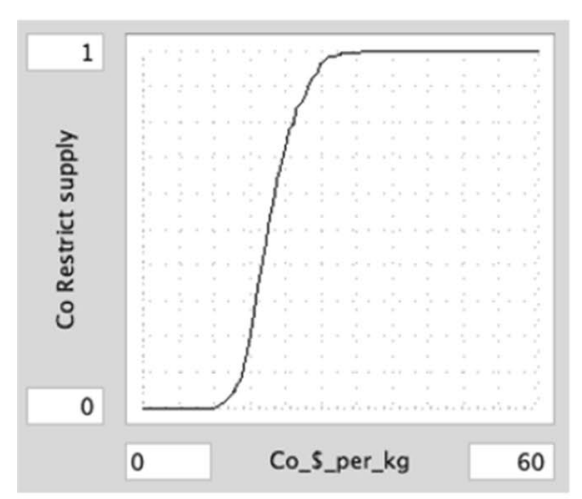

a

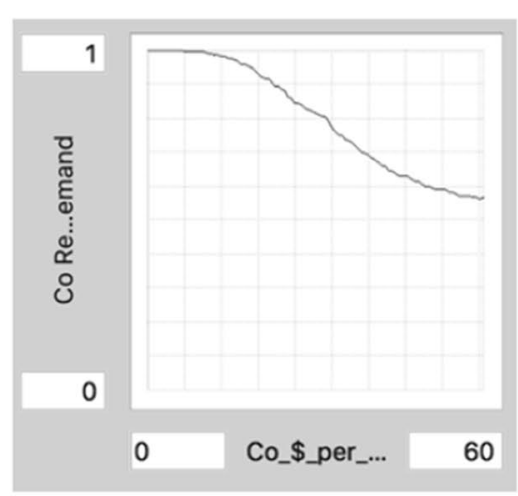

b

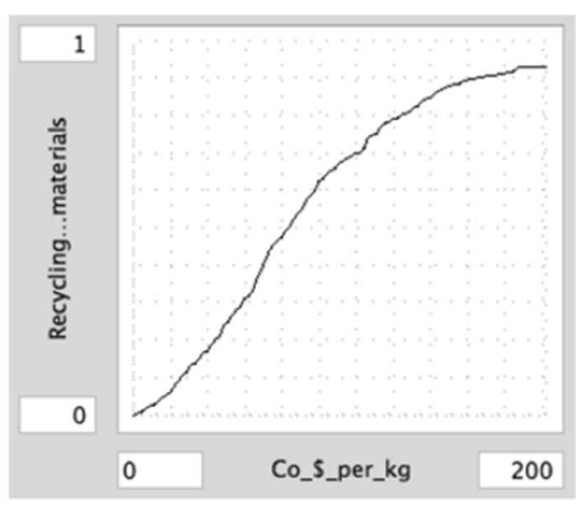

c

Fig. 10 The applied price feedback function for the restriction on supply (a) and demand (b). c The applied feedback function for the fraction recycled materials as a function of price (see the CLD shown in Fig. 3 where in the model this feedback is used) 


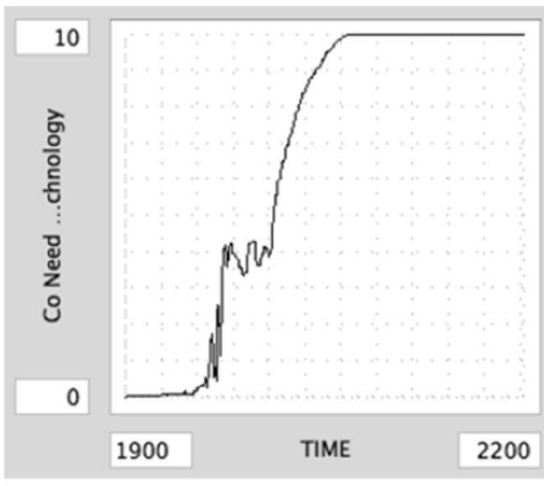

$\mathbf{a}$

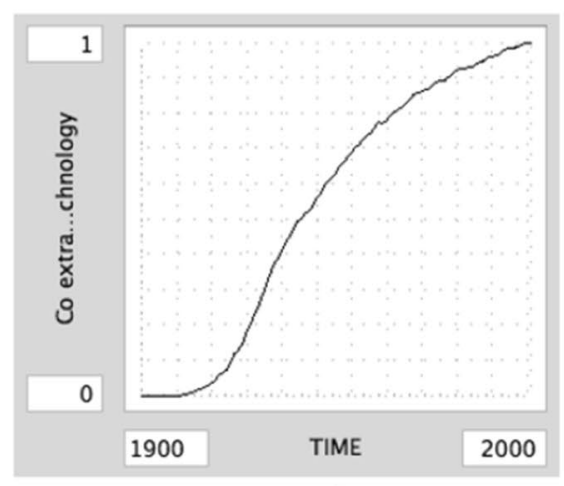

b

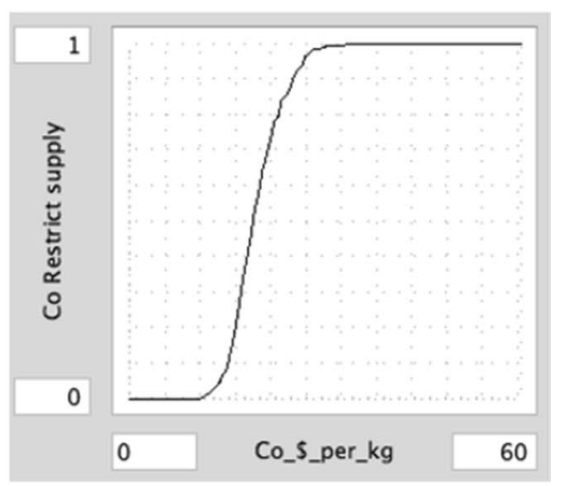

c
Fig. 11 a The applied increase in demand per person from the technological development of new industrial cobalt uses. This is an input curve. b The efficiency of the cobalt extraction technology and meth- ods. c The applied restriction on hard rock cobalt mining and ocean mining from price feedbacks
Fig. 12 Share of total cobalt supply going to super-alloys and batteries. a Market share of cobalt; $\mathbf{b}$ the switching price for changing from land-based mining to ocean floor-based mining

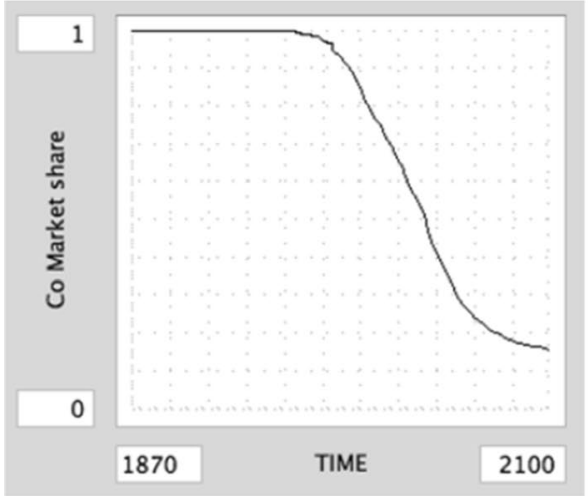

$\mathbf{a}$

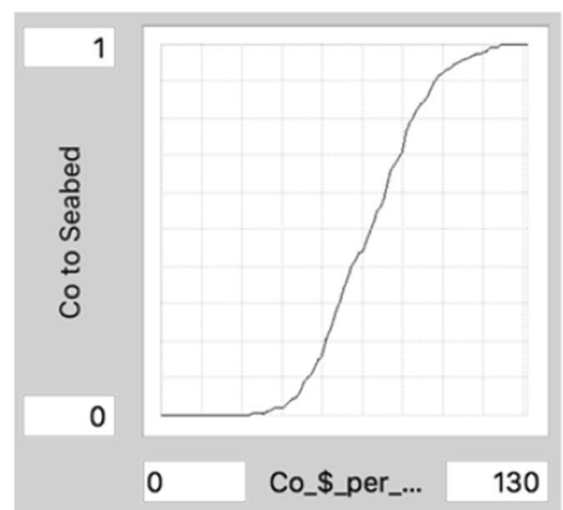

b
A certain price level for cobalt must be reached before it becomes profitable to start mining from the ocean floor. Figure $12 \mathrm{~b}$ shows the switching price for changing from land-based mining to ocean floor-based mining.

The market research organization CRU in their Cobalt Market Outlook 2015 (Spencer and Searle 2015), forecast a progressive tightening of the supply-demand balance out to 2020 and beyond; "A serious deficit is anticipated by 2020 which will probably generate a supply response from China and the Democratic Republic of Congo. Beyond 2020, a change in battery cathode chemistry which does not use cobalt could bring the market back into surplus." The market mechanisms cannot extract above the content potential in the mother metal flows. This limits the flexibility of the cobalt production. The primary cobalt production thus only partly responds to market mechanisms. We assume the concentration in the refinery residuals used for cobalt extraction to remain constant, even when the ore grade of the mother metal ore grade decline.

Figure 13 shows an overview of the built-in sub-modules in the WORLD6 model as it stands at the time of writing. Dotted boxes show sub-modules under development at present. The black box in the diagram is the World3 model of Meadows et al. (1972, 1974, 2005). The World3 model had all resources of any kind lumped (including fossil energy), into one general resource, making the World 3 resource simulation very difficult to translate to real-world data. An adjusted version of World3 population dynamics were kept in WORLD6 from World3. The other parts are new additions to the World3 model, dealing with metals, phosphorus, energy, materials and climate change, are developed by the authors. Additional work is undergoing to update the economic model to a biophysical economic model as well as including governance, social trust and income distributions as a part of other Research Programmes. COBALT is the submodel inside the purple box in Fig. 13 and shown in Fig. 7. 

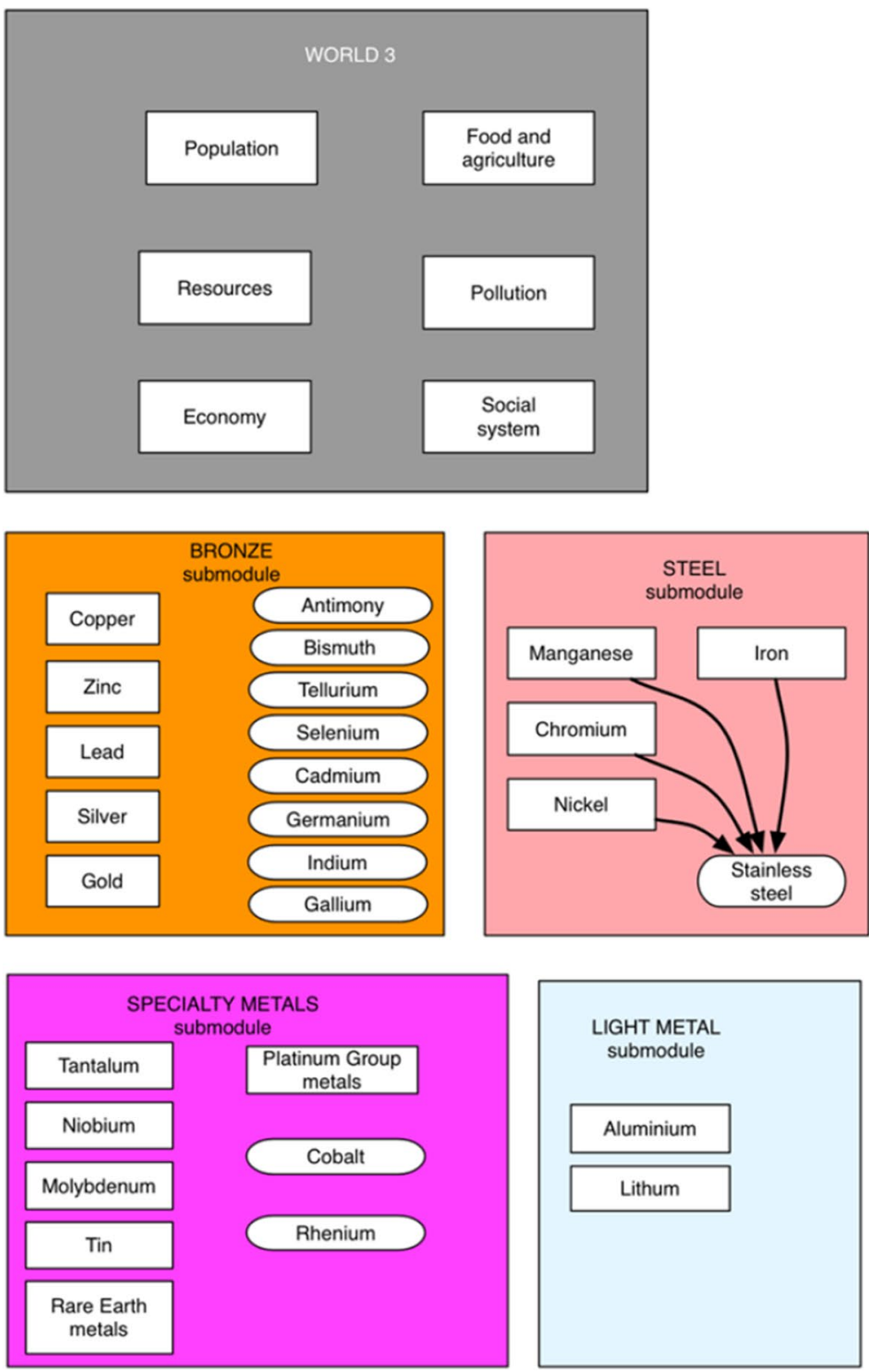

Fig. 13 Overview of the functions in the WORLD6 model. The box coloured grey is the World3 model of Meadows et al. 1972, updated in 2004 by Dr. J. Randers (Meadows et al. 2005) and further changed, added to and modified in 2014-2017 by Dr. Harald Sverdrup and Dr. Deniz Koca at Lund and Iceland Universities. The other parts are new additions to the WORLD6 model dealing with metals, phospho-

\section{Results}

\section{Basic Model Setup}

We ran the COBALT model as integrated in the WORLD6 model with the three different population scenarios shown in Fig. 9, the World3 scenario (W3) (using the same way to estimate the global population as was done with the original World3 1992 version), the base case scenario with
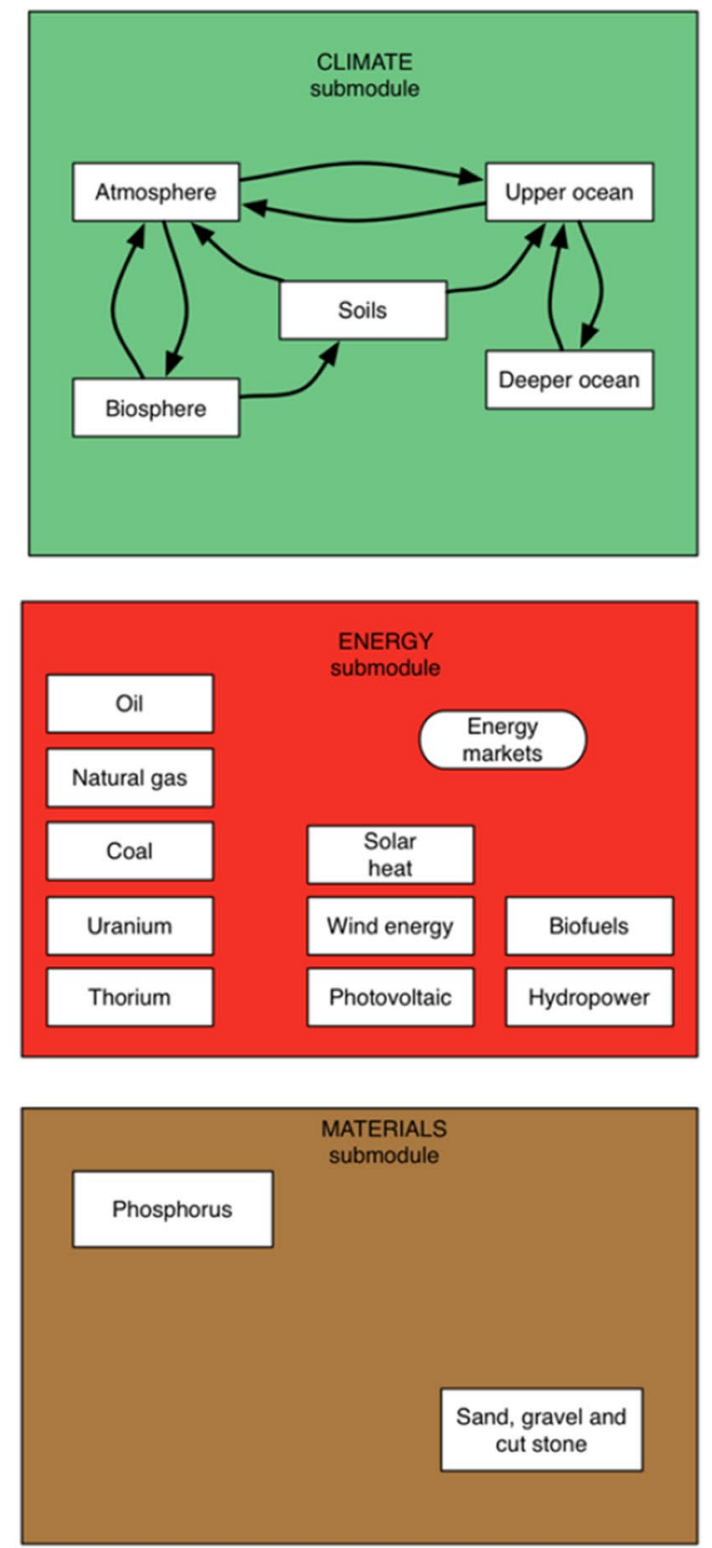

rus, energy, different solid materials and climate change. A WorldWood module for the World's forest dynamics is in advanced state of integration. A financial module based on accounts and stocks with derivatives trade and debts and loans are near completion. Cobalt is a sub-model inside the specialty metals module in the purple box in the figure

the WORLD6 model (W6) and the United Nations population scenario (UN). The different scenarios result in different cobalt demands, and thus also different types of cobalt scarcity, three different cobalt total supply scenarios and cobalt market price trajectories as will be evident from the results shown in the following text. Runs with the COBALT submodel were made for the time 1900-2400 to see how long the available amount for extraction would last. We have done all the simulations using a resource 
estimate of $\mathrm{URR}_{\text {Land }}=32$ million ton cobalt on land and $\mathrm{URR}_{\text {Ocean }}=34$ million ton at the bottoms of the oceans, in cobalt crusts and massive sulphides, a total of 76 million ton (Table 9). We have included primary hard rock mining, secondary extraction from copper, nickel, chromium and platinum group metals (PGM), and from old mine waste dumps, and from 2020 on from ocean seabed mining, using the ocean seabed resource estimate of Mudd and Jowitt (2014). Including a larger estimate for ocean seabed resources did not change anything significantly before 2200, because of the higher costs of extraction. This favours land-based resources and recycling as primary sources of cobalt until after 2200 .

\section{The Base Case Scenario}

Figure 14a shows the primary extraction rate as reconstructed by the COBALT submodel for the past 115 years and predicted for the future from 2015 to 2200 . Not all of the mined cobalt go to metal, but a significant part is used for industrial chemicals, batteries and in pigments. The dots are observed values. It can be seen from Fig. 14a that observed mining rates are the same as given by the model To note is that they are not fitted, the mining data were not used to calibrate the model. Figure $14 \mathrm{~b}$ shows the supply rate to society for cobalt as compared to the extraction rate and the cobalt recycling rate. It can be seen how recycling can be expected to supply larger amounts than primary extraction after 2120 . It can also be seen that in 2080, recycling will become a larger source of cobalt than extraction. The supply is larger than the extraction rate. In 2080, recycling will become a larger source of cobalt than extraction. The extraction rate reaches a maximum at about 155,000 ton per year in 2025 , while the supply reaches a maximum of 250,000 ton cobalt per year in 2065. After 2100-2120

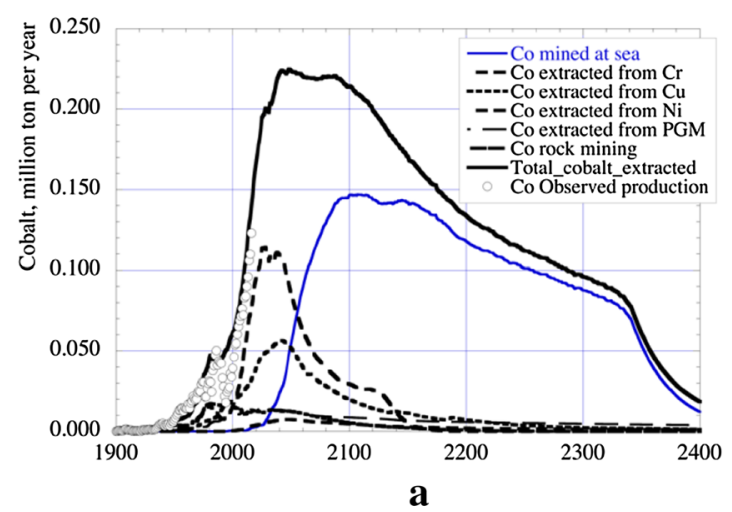

Fig. 14 a The mining rate as reconstructed by the COBALT model, as well as from which mother metal. The dots show the actual mining rate (the model is not fitted to these). The importance of cobalt supply from secondary extraction from copper and nickel mining is evident. there is a decline in supply. The chromite deposits of South Africa and Zimbabwe are used less for cobalt extraction than what could actually be done. The decline is both due to declining resources, but also a decline in population size-driven demand after 2060 (see Fig. 9).

Figure 15a shows the cobalt supply to different product segments. All curves show a peak and subsequent decline. The supply stays at sufficient levels until 2130, when it starts to decline. Figure $15 \mathrm{~b}$ shows the simulation of the price as compared to the observed data. The price shoots up when cobalt runs into hard scarcity 2360 . Figure $16 \mathrm{a}$ shows the origin of the cumulative cobalt extraction in million ton per year. The total amount cobalt extracted to 2200 is about 24 million ton, where 4.5 million ton cobalt is extracted from copper mining, 7.5 million ton cobalt is extracted from nickel mining, 1.8 million ton cobalt is extracted from chromium mining and 2 million ton cobalt is extracted from platinum group metals mining to 2400 . Figure $16 \mathrm{~b}$ shows the cumulative amount cobalt supplied to the markets, the total amount cobalt extracted to the markets and the cumulative cobalt losses to 2200 .

Figure 17a shows the total extracted amount for the different population scenarios explained in the text and in Fig. 9. UN is the United Nations population forecast, W6 is the estimate of the WORLD 6 model and W3 is the updated World3 estimate using the model from 1992. Figure 17b shows the price-adapted demand and the actual supply from the market. Figure 17c shows the amount cobalt deriving from mining at sea. Figure 17d shows the recycling degree for the different scenarios. The recycling rates are dependent on the market price and have no additional social mechanisms or governmental actions involved. The recycling works reasonably well for metallic cobalt in super-alloys and other specific metallic uses since 1978-1980 when new and better technology was developed. For other use such as

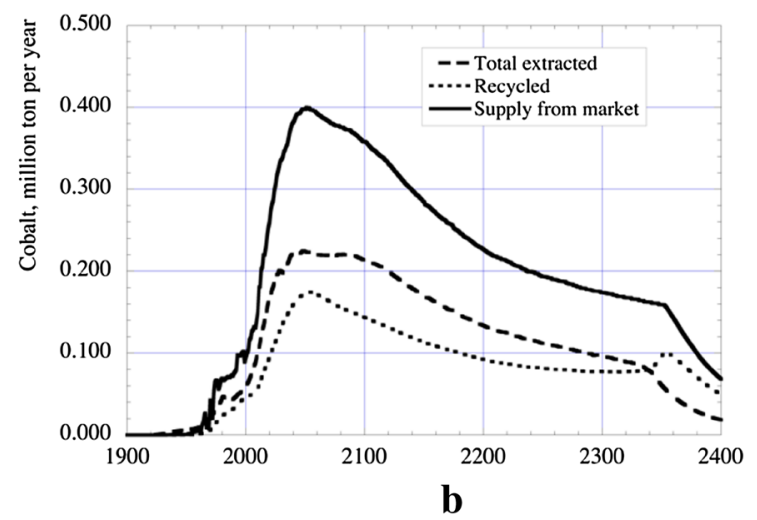

The circles are the observed extraction rates (USGS 2015). b The cobalt extraction, the supply to the market and the amount derived from recycling 


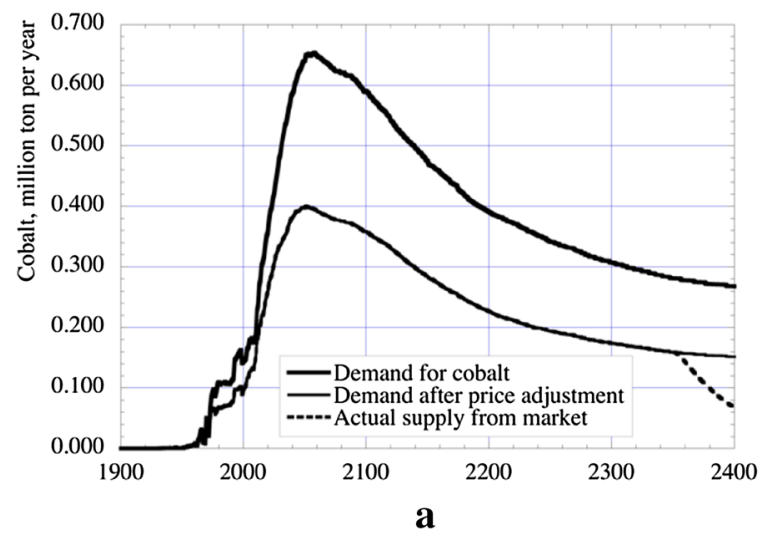

Fig. 15 a How the price-adjusted demand (a) separates from the demand from the market. This is what we defined as soft scarcity. From 2360, hard scarcity is visible, when price-adjusted demand

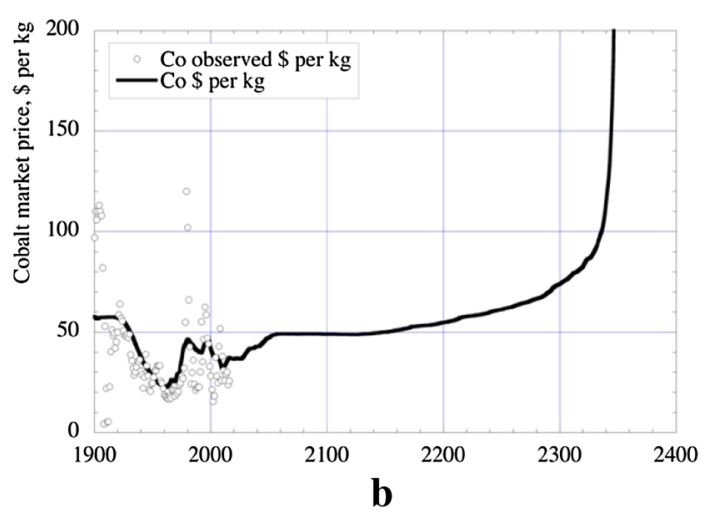

cannot be fulfilled. b The simulation of the price as compared to the observed data. The price shoots up when cobalt runs into hard scarcity 2360
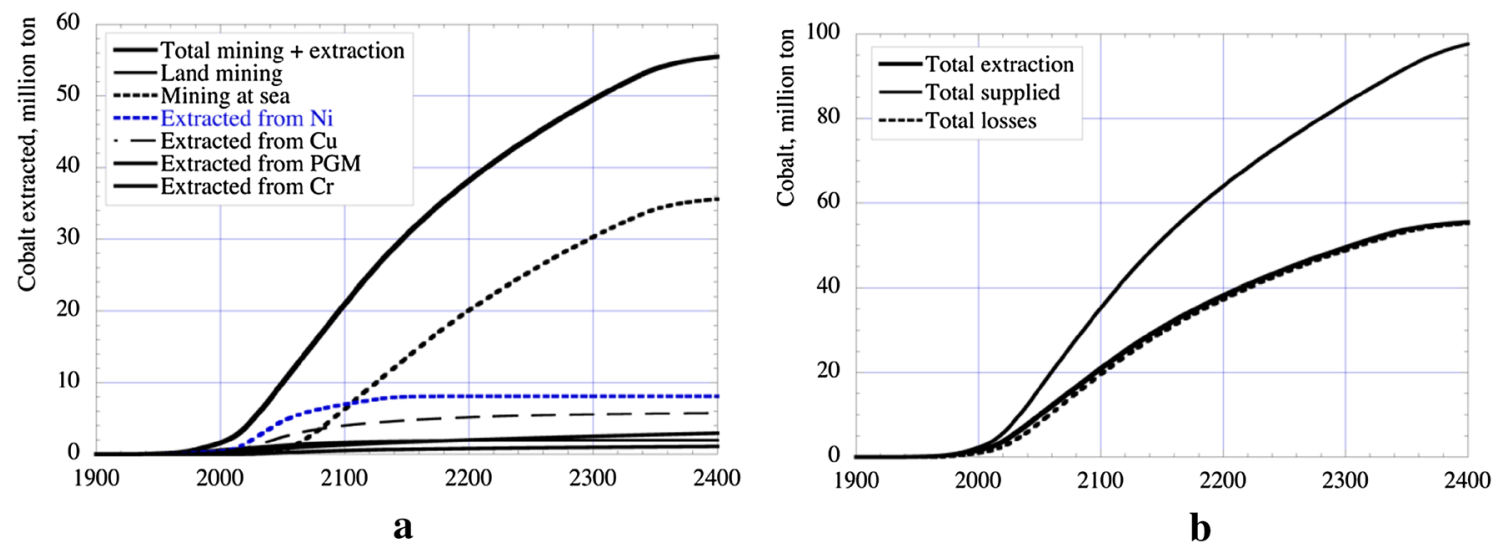

Fig. 16 a The cumulative amounts cobalt extracted from nickel, copper and PGM, and the total extracted amounts. b The cumulative amount supplied, the total amount extracted and the cumulative losses to $2400 \mathrm{AD}$

paints, pigments, chemicals or chemical catalysts, recycling is virtually non-existent.

Most of the cobalt in these uses gets lost or goes to landfills. The recycling rates are dependent on the market price, but will not go above $45 \%$ unless something more than just market mechanisms are used. In the time period from 2080 to 2120 , the recycling rate increases as a market response to increased market prices. By market forces alone, recycling improves towards 2100 , but by then far too much cobalt will have been wasted and lost diffusively. When compared to the recycling rates reported by the International Resource Panel (UNEP 2011a, b, c, 2012, 2013a, b, c), it becomes apparent that estimates of recycling rates at single point in time are very uncertain.

Figure $18 \mathrm{a}, \mathrm{b}$ shows the price in a longer perspective. The model gives price in 1998 value-adjusted prices in US dollars per kg cobalt. Scarcity becomes serious after 2050 with sharply increasing cobalt price in the intermediate and high population scenario. For the low scenario, nothing much happens with the price until after 2400 , beyond our time horizon. The relationship between total extracted and total supplied is about 1.8, Factor X. Factor X is an indicator for the resource use efficiency in society. Factor X can be changed by changing the degree of recycling.

\section{Comparing the Base Case with the High-, Intermediate- and Low-population Scenarios}

Additional runs were made to investigate the importance of global population size. The reader can compare the different outcomes in Figs. 17 and 18. Figure 17a shows the total extracted amount for the different population scenarios explained in Fig. 9. It can be seen that the higher population leads to a higher demand, causing a higher extraction and a faster depletion of the extractable resources. Under the UN population scenario, cobalt extraction runs out in 2230 , the 

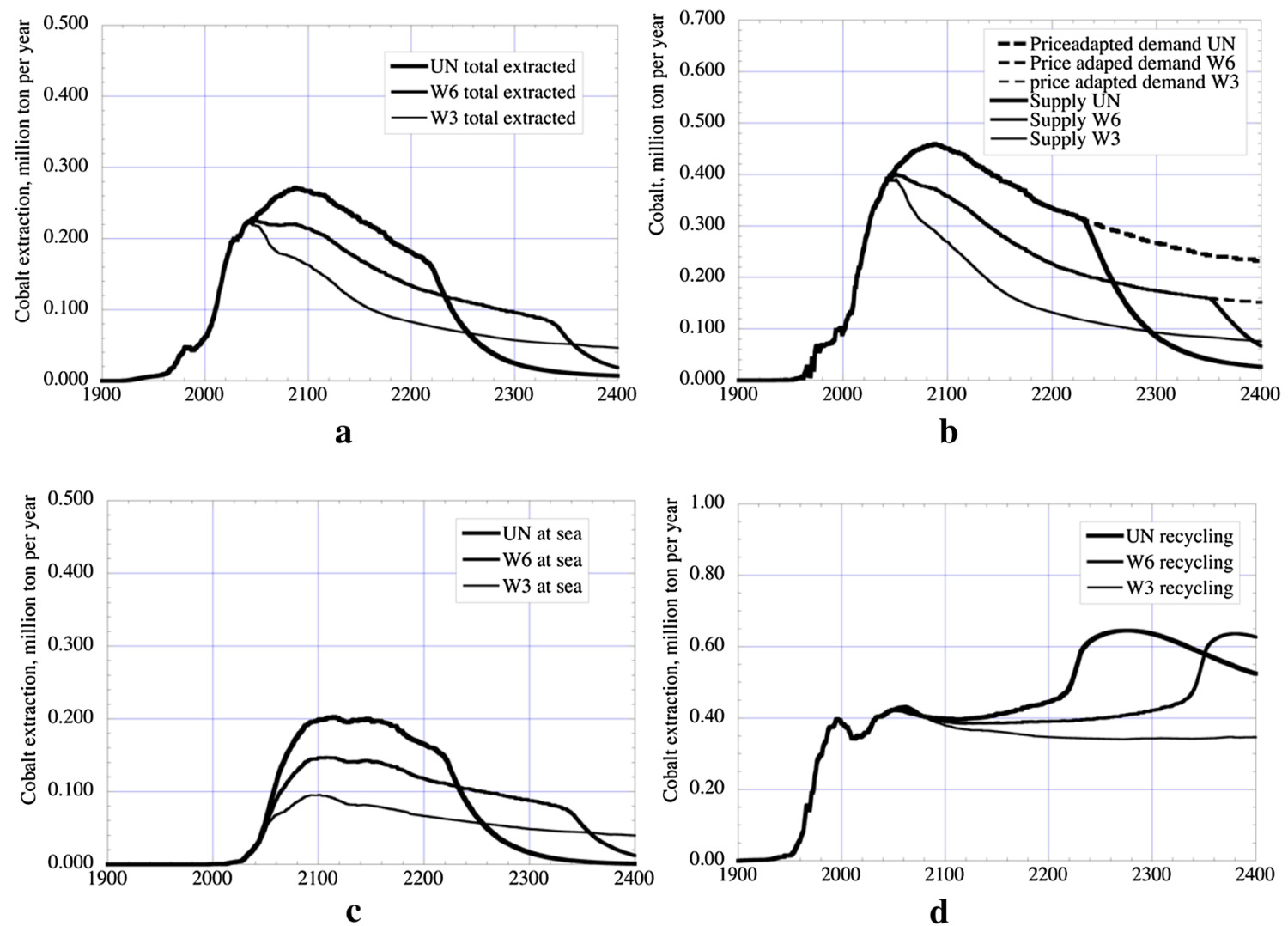

Fig. 17 a The total extracted amount for the different population scenarios explained in the text and in Fig. 9. UN is the United Nations population forecast, W6 is the estimate of the WOR 6 model and W3 is the updated World3 estimate using the model from 1992. b The

price-adapted demand and the actual supply from the market. $\mathbf{c}$ The amount cobalt deriving from mining at sea. d The recycling degree for the different scenarios
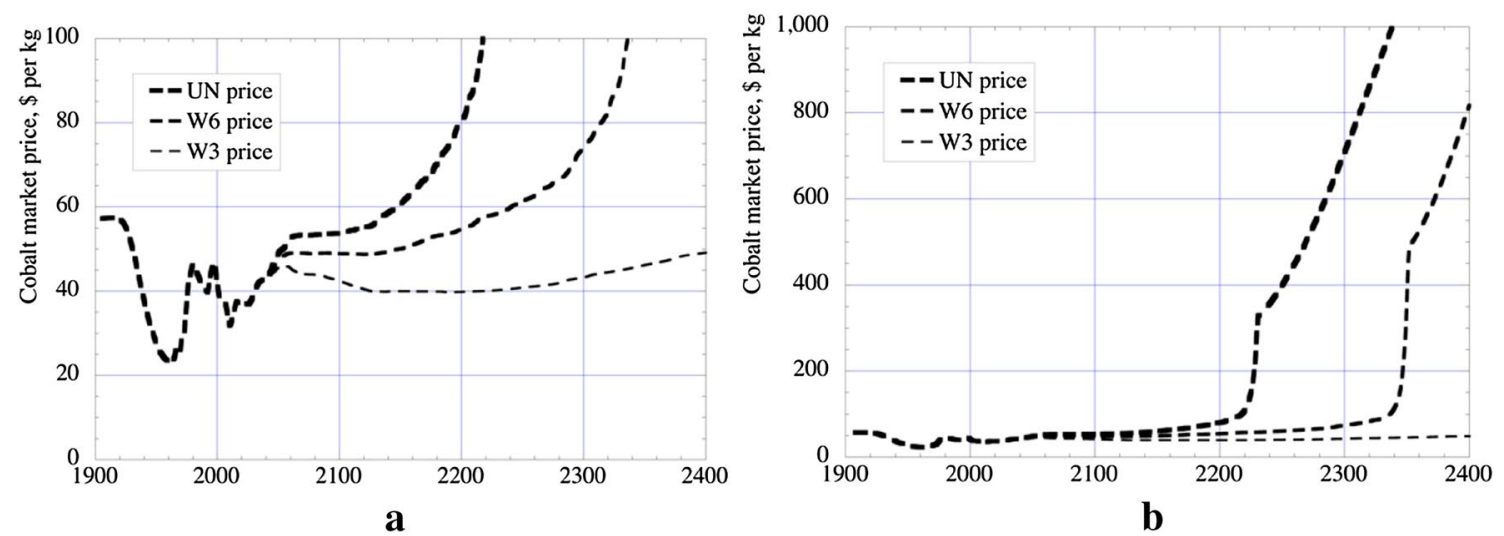

Fig. 18 The diagrams show the price trajectory for cobalt for the different population scenarios, the same diagram but in different scaling

price rises sharply after 2130 and increases both recycling degree and mining at sea. The effect is also seen under the WORLD6 population scenario, but not in the World3 scenario. It can also be seen how the higher demand under the UN and WORLD6 scenarios also drives both land and sea resources (Fig. 18c) to exhaustion. In the World3 scenario this does not happen until very much later or possibly never. Figure $17 \mathrm{~b}$ shows the price-adapted demand (after adjustment for soft scarcity) and the actual supply from the market. It can be seen how hard scarcity for cobalt sets in under the WORLD6 and UN populations scenario. Hard scarcity sets in in 2230 for the UN scenario and in 2360 in 
the WORLD6 scenario, but never in the World3 scenario. Figure $17 \mathrm{c}$ shows the amount cobalt deriving from mining at sea, which is much dependent on a high cobalt market price. Figure $18 \mathrm{~d}$ shows the recycling degree for the different scenarios. The differences between the scenarios are driven by differences in price as shown in Fig. 18a, b for the different population scenarios, the same diagram but in different scaling.

\section{Discussions}

\section{Test and Uncertainties}

In Fig. 14a we show a tests of the model on the cobalt extraction rate to the observed extraction rate (dots in figure), it gives a correlation of $r^{2}=0.96$. Figure $15 \mathrm{~b}$ shows the modelled price as US dollars per $\mathrm{kg}$ value-adjusted to 1998 for $1900-2020$ as compared to the observed running current market price and the observed price in US dollars per $\mathrm{kg}$ value-adjusted to 1998 and the observed price in the markets. For the period 1920-1990, we get the level in price right (Fig. $15 b, r^{2}=0.44$ ), but all the observed price volatility in the market is not captured by the WORLD6 model. The accuracy of the price simulations is quite sensitive to the price-to-market-stock curve used, and the observed price curve shown (Fig. 8b) has the best performance. The discrepancy between observed and modelled price is also caused by difficulties in setting historic demand levels, the short-term variations in the demand and uncertainties in the demand-price and supply-price feedback functions applied in the cobalt model. The reason for this may be the inability to capture periods of disruption in major producing countries a priori as well as the effect or market speculation and financial manipulations, which are not included in the model at present.

Some readers may react to the runs being run as far into the future to 2400 . This may seem bold, but it must be remembered that in contrast to statistical data driven models, causally based models with coupled mass and energy balanced become quite well confined for substantial periods of time. This is supported by the fact that the same model (WORLD6) has been used to model trajectories from 1850 to the present (165 years) for copper, zinc, lead and iron to give examples, and from 1750 to the present (265 years) for silver and gold, being able to reconstruct the past production and market process with good accuracy (Sverdrup et al. 2012a, b, 2014a, b). This was accomplished without excessive calibration, and these fundamental settings were kept throughout the runs (Figs. 8, 10, 11, 12; Table 10).
Output Sensitivity to Population Size, Affecting Demand

We have used the base run of the WORLD6 model for the estimates. As an alternative, we used the United Nations estimates. They are only based on demographic dynamics, and assume that the resource supply situation is sufficient at all times and will never ever become limiting. In the WORLD6 model, food supply as affected by phosphate availability, agricultural land development including soil erosion and energy availability is considered in the simulation of population dynamics. Cobalt has marginal effect on this, but the population has a large effect on cobalt. This leads to a very different population dynamics as a result of feedbacks from the global mass balances and energy balances. Our opinion is that a population model with no feedback from energy availability or food availability is not very realistic, and probably gives an over-prediction of the long-term sustainable population.

\section{Ore Grades and Reserves}

Over time, the grades for cobalt have declined in parallel with the decline in ore grade of the parent metals nickel, copper and PGM (Mudd 2007, 2009a, b, 2010a, b, 2012; Mudd et al. 2013a, b. Sudbury (Canada) and other similar nickel sulphide ores have today $1-0.5 \mathrm{~kg}$ nickel per ton rock, the laterite ores have 1-10 kg nickel per ton material, the cobalt ore in Katanga, Republic of Congo has a cobalt content $2-10 \mathrm{~kg}$ cobalt per ton rock. The bulk cobalt ore grade have gone down about a factor 3-5 over the last 40 years, following the declining ore grade of the mother metal ores for nickel and copper (Mudd 2007, 2009, 2010a, b, 2012; Mudd et al. 2013a, b). As the mother metal ore grades are low in the mother metal deposits, cobalt extraction indirectly implies a large environmental impact. If the cobalt reserves run out, and the metal has been diffusively lost, we will simply have no cobalt available when the stock in society is gone. The systemic cobalt recycling rate at present is far too low to be acceptable from a point of view of long-term metal conservation, and it is appropriate to consider policy measures to strengthen cobalt conservation in society.

\section{Substitution}

Substitution is partially possible for some of the applications of cobalt (Slack et al. 2010). In magnets, several rare earths provide alternatives, and the use of cobalt there is flexible. Rare earths are more abundant than cobalt, and provide a real and good functional substitute. Substitution in cutting tools and in pigments is trivial and straight forward, and good alternatives exist. 
In super-alloys, there are not any good functional substitutes for cobalt, and this may become a problem for largescale production of high-performance jet turbines. It may only partly be replaced by nickel. The platinum group metals, niobium or rhenium may in some situations substitute for some of the cobalt, but niobium and rhenium are rarer in nature than cobalt, and thus the capacity for supplying the amounts needed for full substitution are not there. After 1980, super-alloy recycling increased significantly due to technical advances, improving cobalt supply. But further improvements are necessary (Alonso et al. 2007; Alonso 2010; Sverdrup and Ragnarsdottir 2017).

For chemical catalysts, some of the used cobalt may be substituted with platinum and palladium, but with a loss of performance and at a significantly higher cost. The platinum group metals are very limited in supply when compared to cobalt, and for any need in larger volumes, they will be totally insufficient. For some uses there is no functioning replacement for cobalt, but some work-around strategies is possible.

In lithium battery technology, cobalt plays an important role for battery durability, number of battery recharging cycles and stability of the storage capacity with time. The substitutes manganese, nickel or rare earths have inferior function, leading to heavier batteries. The use of cobalt in battery technology requires weight amounts comparable to or larger that of lithium and may exceed the available cobalt production rate in the near future.

\section{The Need for Dynamic Modelling}

It is important to include dynamic market features and feedbacks in assessment used for policy development. Some policies depend on assumptions on market mechanisms being able to allocate resources most efficiently, and this needs to be modelled with feedbacks involved and tested to verify or falsify such assumptions. For those metals we have assessed so far (copper, zinc, lead, silver, gold, platinum, palladium, cobalt, lithium, iron, aluminium, manganese, chromium, nickel, tantalum, molybdenum, rhenium), market mechanisms were inadequate for sustainable management of the materials, calling for substantial governance actions and measures.

\section{Ocean Cobalt Mining}

Ocean bed mining of cobalt was included in the model. Because of cost constraints, the amounts being mined turned out to be insignificant as compared to land-based extraction for the period from now to about 2050. The model predicts that ocean mining will become significant when significant price increases will make extraction payable (Figs. 17, 18). However, because of the high costs and low profit potential as compared to recycling, the amounts never become really significant until after 2050 for any of the scenarios. For the higher population pressures under WORLD6 and UN population estimates, sea mining can become significant and even run those resources to exhaustion. No technology exists for doing subsea mining on a large scale at present, what exist are proposals and early prototypes (Beckmann 2007; Allsopp et al. 2013). The long term environmental challenges have so far no solution (Herzing and Hannington 1995; Beckmann 2007; Zhou 2007; Clark et al. 2010, 2013; Allsopp et al. 2013, Mudd et al. 2013b; Smith and Heydon 2013; Schmidt 2015; Tainter 1990). Large technological and environmental obstacles must be overcome for the ocean seabed alterative to become realistic (Beckmann 2007). The cobalt crusts are located from $800 \mathrm{~m}$ depth to $3500 \mathrm{~m}$ depth in the oceans, and associated manganese nodules are normally from 1000 to $5000 \mathrm{~m}$ depth, and it is not going to be an easy task to get them up to the surface (Clarke et al. 2010, 2013c; Clarke and Smith 2013a, b; Allsopp et al. 2013). The work will require advanced robotics and is likely to incur substantial cost that can only be carried out at a price significantly higher than the present market price.

\section{The Next Step in Model Development}

The next steps are possible, because the COBALT submodel is integrated in the WORLD6 model. By running it in conjunction with the LITHIUM submodel in WORLD6, we can take into account demand from lithium-based battery technology. Inside the WORLD6 model are modules handling the metals that go into making super-alloys for high-performance turbines, air superiority jet fighter highperformance engines and rocket engines (nickel, cobalt, niobium, molybdenum, rhenium, tantalum, hafnium and PGM). This allows assessment of any scarcity issues for these types of products.

\section{The Issue of Population}

Throughout the internal market dynamics inside the WORLD6 model, the size of the population is very important. Demand is composed of use per capita, the efficiency of use and the number of consumers. The number of consumers is another name for the global population size. Thus, the issue of population cannot be ignored. We have adopted three population scenarios, the UN forecast, the WORLD6 estimation and the Word3 estimation from 1972. We think the World3 1972 estimation is somewhat too low, and we think the UN estimate is a naïve estimate ignoring all feedbacks from resources like energy, land and phosphorus. Our own opinion is based on what we consider to be the best available estimate according to present scientific 
knowledge, considering world systems feedbacks, as done with WORLD6.

\section{Conclusion}

The present use of cobalt shows a low degree of recycling and systemic losses are significant. The extractable resources of cobalt are not very large, about 32 million ton extractable from land-based resources and about 34 million to from ocean seabed resources, a maximum of about 66 million ton. Some time after 2200, the supply of cobalt will have run out under a business-as-usual scenario, depending on the population scenario adopted. Too much cobalt is lost if only market mechanisms are expected to improve recycling, and unnecessary cobalt is wasted if no policy actions are taken. We can conclude that the market mechanisms alone do neither have the goal nor the competence to make cobalt use sustainable without governmental interventions and regulations. A science-based solutionoriented policy is needed to correct the situation before it is too late and too much cobalt has been lost. Failure to take this message in will risk that society one day will be without cobalt. To conserve cobalt and allow it to be available for coming generations, present policies must be changed and the large observed losses mitigated within the next decades.

Acknowledgements This study contributed to the SIMRESS project (Models, potential and long-term scenarios for resource efficiency), funded by the German Federal Ministry for Environment and the German Environmental Protection Agency (FKZ 371293 102), the SIMRESSS Aufstockungsauftrag (FKZ 371293 102) and the SIMRESS Climate Impact Analysis project (FKZ 371632100 0). Other partners to the SIMRESS project are Ecologic Institute, Berlin, Germany; the Institute of Economic Structures Research, GWS, Osnabrück, Germany; and European School of Governance (EUSG), Berlin, Germany. Dr. Ullrich Lorenz is project officer at the German Environmental Protection Agency (UBA).

\section{References}

Allen DT, Behamanesh N (1994) Wastes as raw materials. In: Allenby BR, Richards DJ (eds) The greening of industrial ecosystems. National Academy Press, Washington, DC, pp 68-96

Allsopp M, Miller C, Atkins R, Rocliffe S, Tabor I, Santillo D, Johnston P (2013) Review of the current state of development and the potential for environmental impacts of seabed mining operations. Greenpeace Research Laboratories Technical Report. 03-2013. https://www.oceanfdn.org/sites/default/files/seabedmining-tech-review-2013.pdf. Accessed May 2015

Alonso E (2010) Material scarcity from the perspective of manufacturing firms: case studies of platinum and cobalt. $\mathrm{PhD}$ thesis from Materials Science and Engineering, MIT, Boston. http:// msl.mit.edu/theses/Alonso_E-thesis.pdf. Accessed May 2015
Alonso E, Frankfield JG, Kirchain R (2007) Material availability and the supply chain: risks, effects, and responses. Environ Sci Technol 41:6649-6656

Bardi U (2013) Extracted. How the quest for mineral wealth is plundering the planet. The past, present and future of global mineral depletion. A report to the Club of Rome. Chelsa Green Publishing, Vermont. (ISBN 978-1-60358-541-5)

Beaudoin Y, Bredbenner A, Baker E, Roche C, Bice E, Pendleton L, (2014) Thematic focus: environmental governance, resource efficiency. Wealth in the Oceans: deep sea mining on the horizon? http://www.unep.org/geas. GEAS 2014. Accessed May 2015

Beckmann A (2007) The physical environment of cobalt-rich ferromanganese crust deposits, the potential impact of exploration and mining on this environment, and data required to establish environmental baselines. In: ISA (ed) Polymetallic sulphides and cobalt rich ferromanganese crust deposits: establishment of environmental baselines and an associated monitoring programme during exploration. In: Proceedings of the International Seabed Authority's workshop, Kingston, 6-10 Sept 2004, pp 227-250

Berger VI, Singer DA, Bliss JD, Moring BC (2011) Ni-Co laterite deposits of the world; database and grade and tonnage models: US Geological Survey Open-File Report 2011-1058. http://pubs.usgs.gov/of/2011/1058/. Accessed May 2015

Berry C (2015) TA closer look at nickel: an unsustainable current reality? Disruptive Discov J. http://www.discoveryinvesting. com/blog/2015/10/20/a-closer-look-at-nickel-an-unsustainable-current-reality. Accessed May 2015

Boliden AB (2011) Rönnskärsveket, Sundsvall, Sweden. Metals for the future. Corporate brochure. http://www.boliden. com/Operations/Exploration/Ore-Reserves-and-MineralResources/, http://www.slideshare.net/miningontop/base-metals-outlook-for-supply-and-demand. Accessed May 2015

Boschen RE, Rowden AA, Clark MR, Gardner, JPA (2013) Mining of deep-sea seafloor massive sulfides: a review of the deposits, their benthic communities, impacts from mining, regulatory frameworks and management strategies. Ocean Coast Manag 84:54-67

Brandt G (1735) Dissertatio de semimetallis. Acta Lit et Sci Svec $4: 1-10$

Brandt G (1746) Rön och anmärkningar angäende en synnerlig färg-cobolt. Kongliga Sven vetensk handl 7:119-130

Brandt B (1748) Cobalti nova species examinata et descripta. Acta Regiae Soc Sci Ups 1st Ser 3:33-41

Brown TJ, Wrighton CE, Raycraft ER, Shaw RA, Deady EA, Rippingale J, Bide T, Idoine N (2015) World mineral production 2009-13. Nottingham British Geological Survey, Keyworth (ISBN 978-0-85272-848-2)

Cailteaux JKH, Kampunzu AB, Leroughe C, Kaputo AK, Milesi JP (2005) Genesis of sediment-hosted stratiform coppercobalt deposits, central African Copperbelt. J Afr Earth Sci 42:134-158

Clark M, Smith S (2013a) Chapter 3.0: environmental management considerations. In: Baker E, Beaudoin Y (eds) Deep sea minerals: sea-floor massive sulphides, a physical, biological, environmental, and technical review. vol 1A, Secretariat of the Pacific Community

Clark M, Smith S (2013b) Chapter 3.0: environmental management considerations. In: Baker E, Beaudoin Y (eds) Deep sea minerals: manganese nodules, a physical, biological, environmental, and technical review. vol 1B, Secretariat of the Pacific Community

Clark MR, Rowden AA, Schlacher T, Williams A, Consalvey M, Stocks KI, Rogers AD, O'Hara TD, White M, Shank TM, 
Hall-Spencer J (2010) The ecology of seamounts: structure, function, and human impacts. Ann Rev Mar Sci 2:253-278

Clark MR, Heydon R, Hein JR, Petersen S, Rowden A, Baker E, Beaudoin Y (2013) Deep sea minerals: cobalt-rich ferromanganese crusts, a physical, biological, environmental, and technical review. In: Baker E, Beaudoin Y (eds) vol 1C, Secretariat of the Pacific Community (ISBN 978-82-7701-121-9)

Cobalt Facts (2011) Properties and main uses (3 pages), Metalurgical uses (15 pages), Magnetic alloys (6 pages), Cobalt supply and demand 2010 (8 pages), Cobalt in chemials (12 pages), Cobalt in cemented carbides (5 pages), Cobalt in electronics (6 pages). The Cobalt Development Institute. http://www.thecdi.com/ cobaltfacts.php. Accessed May 2015

Cobalt/Investing News (2014) The top 10 list of cobalt production by country. Investing News Network website. http://investingnews. $\mathrm{com} /$ daily/resource-investing/critical-metals-investing/cobaltinvesting/top-cobalt-producing-countries-congo-china-canadarussia-australia/. Accessed May 2015

Crowson PCF (2011) Mineral reserves and future minerals availability. Miner Econ 24:1-6

Dahmus JB, Gutowski TG (2007) What gets recycled: an information theory based model for product recycling. Env Sci Tech 41:7543-7550

Dalvi AD, Bacon WG, Osborne RC (2004) The past and the future of Nickel laterites. PDAC 2004 International Convention, Trade Show and Investors Exchange, 7-10 Mar 2004

Davis JR (2000) ASM specialty handbook: nickel, cobalt, and their alloys. ASM International, Charleston, South Carolina

Dawkins E, Chadwick M, Roelich K, Falk R (2012) Metals in a lowcarbon economy: resource scarcity, climate. Change and business in a finite world. Stockholm Environment Institute Project Report. Stockholm, Sweden. http://www.sei-international.org. Accessed May 2015

Diamond J (1997) Guns, germs, and steel: the fates of human societies. W.W. Norton and Co., New York (ISBN 0-393-06131-0)

Diamond J (2005) Collapse. How societies choose to fail or survive. Penguin Books, London

Drake Resources (2015) Nickel in Scandinavia. Internet download, May 2016. http://www.drakeresources.com.au/assets/DRK_ nickel_handout_copy_1.pdf. Accessed May 2015

Eckstrand, OR, Hulbert LJ (2007) Magmatic nickel-copper-platinum group element deposits. In: Goodfellow WD (ed) Mineral deposits of canada: a synthesis of major deposit types, district metallogeny, the evolution of geological provinces, and exploration methods: geological association of Canada, mineral deposits division, Special Publication No. 5:205-222

Eilu P (2011) Metallic mineral resources of Fennoscandia. In: Nenonen K, Nurmi PA (eds) Geoscience for Society 125th Anniversary Volume. Geological Survey of Finland, Special Paper 49:13-21

Eliott $\mathrm{M}$ et al (2014) Business risks facing mining and metals 20142015. EY Report. http://www.ey.com/GL/en/Industries/MiningMetals/Business-risks-in-mining-and-metals. Accessed May 2015

Elshakaki A, Graedel TE (2013) Dynamic analysis of the global metals flows and stocks in electricity generation technologies. J Clean Prod 59:260-273

Geoscience Australia (2009) Australia's identified mineral resources in 2009. Canberra

Gerst M (2008) Revisiting the cumulative grade-tonnage relationship for major copper ore types. Econ Geol 103:615-628

Gerst M (2009) Linking material flow analysis and resource policy via future scenarios of in-use stock: an example for copper. Environ Sci Technol 43:6320-6325

Glöser S, Soulier M, Espinoza LT, Faulstich M (2013a) Using dynamic stock and flow models for global and regional material and substance flow analysis in the field of industrial ecology: the example of a global copper flow model. In: The 31st International Conference of the System Dynamics Society, Cambridge

Glöser S, Soulier M, Espinoza LAT (2013b) Dynamic analysis of global copper flows. Global stocks, postconsumer material flows, recycling indicators, and uncertainty evaluation. Environ Sci Technol 47:6564-6572

Gordon R, Bertram B, Grädel M (2006) Metal stocks and sustainability. Proc Natl Acad Sci 103:1209-1214

Graedel TE, Erdmann L (2012) Will metal scarcity impede industrial use? Metals Res Soc Bull 37:325-333

Graedel TE, van Beers D, Bertram M, Fuse K, Gordon R, Gritsinin A (2004) A multi-level cycle of anthropogenic copper. Environ Sci Technol 38:1242-1252

Graedel TE, Buckert M, Reck BK (2011) Assessing mineral resources in society. Metal stocks and recycling rates. UNEP, Paris (ISBN 978-92-807-3182-0)

Greer JM (2008) The long descent. A users guide to the end of the industrial Age. New Society Publishers, Gabriola Island, Canada

Hagelüken C, Meskers CEM (2009) Complex life cycles of precious and special metals. In: Graedel T, van der Voet E (eds) Linkages of Sustainability. Strüngmann Forum Report, vol 4. MIT Press, Cambridge

Halada K, Shimada M, Ijima K (2008) Forecasting of the consumption of metals up to 2050. Mater Trans 49:402-410

Hannis S, Bide T (2009) Cobalt. Commodity profiles. British Geological Survey, Keyworth

Haraldsson HV, Sverdrup HU (2004) Finding simplicity in complexity in biogeochemical modelling. Book chapter. In: Wainwright J, Mulligan M (eds) Environmental modelling: a practical approach. Wiley, Chichester, pp 211-223

Harmsen JHM, Roes AL, Patel MK (2013) The impact of copper scarcity on the efficiency of 2050 global renewable energy scenarios. Energy 50:62-73

Harper EM, Kavlak G, Graedel TE (2012) Tracking the metal of the goblins: cobalt's cycle of use. Environ Sci Technol 46:1079-1086

Hawkins M (2001) Why we need cobalt. Appl Earth Sci Trans Inst Min Metall Sect B 110(2):66-71. doi:10.1179/ aes.2001.110.2.66

Hein JR, Conrad TA, Dunham RE (2009) Seamount characteristics and mine-site model applied to exploration- and mining-lease-block selection for cobalt-rich ferromanganese crusts. Mar Georesour Geotechnol 27:160-176. doi:10.1080/10641190902852485

Hein JR, Conrad TA, Staudigel H (2010) Seamount mineral deposits, a source of rare-metals for high technology industries. Oceanography 23:184-189

Hein JR, Mizell K, Koschinsky A, Conrad TA (2013) Deep-ocean mineral deposits as a source of critical metals for high- and green-technology applications: comparison with land-based resources. Ore Geol Rev 51: 1-14

Heinberg R (2001) Peak everything: waking up to the century of decline in earth's resources, Clairview, pp 270

Henckens MLCM, Driessen PPJ, Worrell E (2014) Metal scarcity and sustainability, analyzing the necessity to reduce the extraction of scarce metals. Resour Conserv Recycl 93:1-8

Herzig PM, Hannington MD (1995) Polymetallic massive sulphides at the modern seafloor: a review. Ore Geol Rev 10:95-115

Hoagland P, Beaulieu S, Tivey M, Eggert RG, German C, Glowka L, Lin J (2009) Deep-sea mining of seafloor massive sulfides. Marine Policy 34:728-732

Idaho Cobalt Mine United States of America (2015) http://www. mining-technology.com/projects/idaho-cobalt-mine/ (Web-page with mining news) 
International Seabed Authority (2015) Cobalt-rich crusts. https:// www.isa.org.jm/files/documents/EN/Brochures/ENG9.pdf. Accessed May 2015

Johnson J, Harper EM, Lifset R, Graedel TE (2007) Dining at the periodic table: metals concentrations as they relate to recycling. Environ Sci Technol 41:1759-1765

Johnson KM, Hammarstrom JM, Zientek ML, Dicken CL (2014) Estimate of undiscovered copper resources of the world, 2013: US Geological Survey Fact Sheet 2014-3004. doi:10.3133/ fs20143004

Kennedy P (1987) The rise and fall of the great powers: economic change and military conflict from 1500 to 2000. Random House, New York

Kesler SE, Wilkinson BH (2013a) Earth's copper resources estimated from tectonic diffusion of porphyry copper deposits. Geology 41:255-258

Kesler SE, Wilkinson BH (2013b) Tectonic-diffusion estimates of global mineral resources: extending the method-granitic tin deposits. In: Jenkin GRT, Lusty PAJ, McDonald I, Smith MP, Boyce AJ, Wilkinson JJ (eds) Ore deposits in an evolving earth. Geological Society, London, Special Publications. First published online 7 Oct 2013. doi:10.1144/SP393.6

Kwatra S, Jun C, Warren S, Yang M-Y, Graedel TE (2012) Criticality of the geological copper family. Environ Sci Technol 46:1071-1078

Lenzen M (2008) Life cycle energy and greenhouse gas emissions of nuclear energy: a review. Energy Convers Manag 49:2178-2199

Liessmann W (1994) Vom Kobalterz zum Köningsblau. Zur Geschichte des Skuteruder Kobaltbergbaues und des Modumer Blaufarbenwerkes in Südnorwegen. Emser Hefte 15:1-64

Martino S, Parson LM (2011) A comparison between manganese nodules and cobalt crust economics in a scenario of mutual exclusivity. Marine Policy 36:790-800

Meadows DL, Behrens WW III, Meadows DH, Naill RF, Randers J, Zahn EKO (1974) Dynamics of growth in a finite world. Wright-Allen Press Inc, Massachusetts

Meadows DH, Meadows DL, Randers J, Behrens W (1972) Limits to growth. Universe Books, New York

Meadows DH, Randers J, Meadows DL (2005) Limits to growth, the 30 year update. Earthscan, Sterling

Mohr S, Mudd GM, Weng Z, Giurco D (2014a) Modelling future copper ore grade decline based on a detailed assessment of copper resources and mining. Resour Conserv Recycl 83:190-201

Mohr S, Giurco D, Yellishetty M, Ward J, Mudd G (2014b) Projection of iron ore production. Nat Resour Res. doi:10.1007/ s11053-014-9256-6

Mudd GM (2007) Gold mining in Australia: linking historical trends and environmental and resource sustainability. Environ Sci Technol 10:629-644

Mudd GM (2009a) Historical trends in base metal mining: backcasting to understand the sustainability of mining. In: Proceedings of the 48th Annual Conference of Metallurgists, Canadian Metallurgical Society, Sudbury, August Issue

Mudd GM (2009b), Nickel sulfide versus laterite, the hard sustainability challenge remains. In: Proceedings 48th Annual Conference of Metallurgists, Canadian Metallurgical Society, Sudbury, August 2009

Mudd GM (2010a) The environmental sustainability of mining in Australia: key megatrends and looming constraints. Resour Policy $35: 98-115$

Mudd GM (2010b) Global trends and environmental issues in nickel mining: sulfides versus laterites. Ore Geol Rev 38:9-26

Mudd GM (2012) Key trends in the resource sustainability of platinum group elements. Ore Geol Rev 46:106-117

Mudd GM, Jowitt SM (2014) A detailed assessment of global nickel resource trends and endowments. Econ Geol 109:1813-1841
Mudd GM, Weng Z, Jowitt SM (2013a) A detailed assessment of global $\mathrm{Cu}$ resource trends and endowments. Econ Geol 110:108-132

Mudd GM, Weng Z, Jowitt SM, Turnbull ID, Graedel TE (2013b) Quantifying the recoverable resources of by-product metals: the case of cobalt. Ore Geol Rev 55:87-98

Muiños SB, Hein JB, Frank M, Monteiro JH, Gaspar L, Conrad T, Pereira HG, Abrantes F (2013) Deep-sea Fe-Mn crusts from the Northeast Atlantic Ocean: composition and resource considerations. Marine Georesour Geotechnol 31(1):40-70

Nassar NT, Barr R, Browning M, Diao Z, Friedlander E, Harper EM, Henly C, Kavlak G, Kwatra S, Jun C, Warren S, Yang M-Y, Graedel TE (2012) Criticality of the geological copper family. Environ Sci Technol 46:1071-1078

Neumeyer E (2000) Scarce or abundant? The economics of natural resource availability. J Econ Surv 14:307-336

Newman HR (2011) The mineral industries of Morocco and Western Sahara. USGS 2011 Mineral yearbook. http://minerals.usgs. gov/minerals/pubs/commodity/cobalt/. Accessed May 2015

Nickless E, Bloodworth A, Meinert L, Giurco D, Mohr S, Littleboy A (2014) Resourcing future generations white paper: mineral resources and future supply. Int Union Geol Sci

Norgate TE, Rankin WJ (2002) The role of metals in sustainable development. In: Proceedings, Green Processing 2002, International Conference on the Sustainable Processing of Minerals, May 2002, pp 49-55

Northey S, Mohr S, Mudd GM, Weng Z, Giurco D (2014) Modelling future copper ore grade decline based on a detailed assessment of copper resources and mining. Resour Conserv Recycl 83:190-201.

Nuss P, Eckelmann MJ (2014) Life cycle assessment of metals: a scientific synthesis. PLoS One 9:e101298. doi:10.1371/journal. pone. 0101298

Papp JF, Bray EL, Edelstein DL, Fenton MD, Guberman DE, Hedrick JB, Jorgenson JD, Kuck PH, Shedd KB, Tolcin AC (2008) Factors that influence the price of $\mathrm{Al}, \mathrm{Cd}, \mathrm{Co}, \mathrm{Cu}, \mathrm{Fe}, \mathrm{Ni}, \mathrm{Pb}$, Rare Earth Elements, and Zn. US Geological Survey OpenFile Report 2008-1356. http://pubs.usgs.gov/of/2008/1356/pdf/ ofr2008-1356.pdf. Accessed May 2015

Phillips WGB, Edwards DP (1976) Metal prices as a function of ore grade. Resour Policy 2:167-179

Prior T, Giurco D, Muss G, Mason L, Behrish J (2012) Resource depletion, peak minerals and the implication for sustainable resource management. Global Environ Change 22:577-587

Prior T, Daly J, Mason L, Giurco D (2013) Resourcing the future: using foresight in resource governance. Geoforum 44:316-328

Ragnarsdottir KV, Sverdrup H, Koca D (2012) Assessing long-term sustainability of global supply of natural resources and materials. Chapter 5; 83-116. In: Ghenai C (ed) Sustainable development-116. Energy, Engineering and Technologies-Manufacturing and Environment. http://www.intechweb.org. Accessed May 2015

Ramberg IB (2008) The making of a land: the geology of Norway. Geol Soc. (ISBN 978-82-92394-42-7)

Rasilainen K, Eilu P, Halkoaho T, Iljina M, Karinen T (2010a) Quantitative mineral resource assessment of undiscovered PGE resources in Finland. Ore Geol Rev 38:270-287

Rasilainen K, Eilu P, Halkoaho T, Iljina M, Karinen T (2010b) Quantitative mineral resource assessment of platinum, palladium, gold, nickel, and copper in undiscovered PGE deposits in maficultramafic layered intrusions in Finland. Geological Survey of Finland, Report of Investigation 180

Rasilainen K, Eilu P, Äikäs O, Halkoaho T, Heino T, Iljina M, Juopperi $\mathrm{H}$, Kontinen A, Kärkkäinen N, Makkonen $\mathrm{H}$, Manninen T, Pietikäinen K, Räsänen J, Tiainen M, Tontti M, Törmänen T (2012) Quantitative mineral resource assessment of nickel, 
copper and cobalt in undiscovered $\mathrm{Ni}-\mathrm{Cu}$ deposits in Finland. Geologian tutkimuskeskus, Tutkimusraportti 194-Geological Survey of Finland, Report of Investigation 194, 514 pages

Roberts S (2012) Deep-sea and sub-seafloor resources: a polymetallic sulphide and Co-Mn crust perspective. The LRET Research Collegium Southampton, 16 July-7 Sept 2012

Roland B (2015) Trend compendium 2030. Scarcity of resources. September 2015. http://www.rolandberger.com/expertise/trend_ compendium_2030/. Accessed May 2015

Roper LD (2014) Cobalt depletion including recycling. http://arts.bev. net/RoperLDavid/. Accessed May 2015

Rosenqvist IT (1949) Noen observasjoner og refleksjoner omkring Modum Koboltgruver (nedl.). I Fahlbåndene. Nor Geol Tidsskr 27:187-216

Schmidt CW (2015) Going deep—cautious steps toward seabed mining. Environ Health Perspect 123:A235-A243

Searle PJ (2015) Cobalt-Market balance in 2020s? In: The Cobalt Conference, Cobalt Development Institute, Toronto, Ontario, Canada, May 20-21

Senge P (1990) The fifth discipline. The art and practice of the learning organisation. Century Business, New York

Shedd KB (2002) Cobalt. USGS 2011 Mineral yearbook. http://minerals.usgs.gov/minerals/pubs/commodity/cobalt/. Accessed May 2015

Shedd KB (2012) Cobalt. Advanced release, USGS 2011 Mineral yearbook. http://minerals.usgs.gov/minerals/pubs/commodity/ cobalt/. Accessed May 2015

Shedd KB (2015) US and Global Cobalt Statistics and Information from the USGS National Minerals Information Center. The Cobalt Conference 2015 Toronto, Ontario, 20-21 May 2015. http://minerals.usgs.gov/minerals/pubs/commodity/cobalt/. Accessed May 2015 (Power Point presentation)

Singer D (2013) The lognormal distribution of metal resources in mineral deposits. Ore Geol Rev 55:80-86.

Slack JF, Causey JD, Eppinger RG, Gray JE, Johnson CA, Lund KI, Schulz KJ (2010) Co-Cu-Au deposits in metasedimentary rocks-a preliminary report: US Geological Survey Open-File Report 2010-1212, p 13. http://pubs.usgs.gov/of/2010/1212/. Accessed May 2015

Smith S, Heydon R (2013) 4.0 Processes related to the technical development of marine mining. In: Baker E, Beaudoin Y (eds) SPC 2013. Deep sea minerals: cobalt-rich ferromanganese crusts, a physical, biological, environmental, and technical review, vol 1C. Secretariat of the Pacific, pp 41-49

SPC (2012) Pacific ACP states regional legislative and regulatory framework for deep sea minerals exploration and exploitation. http://www.smenet.org/docs/public/FinalDeepSeaMineralsProjectReport.pdf. Accessed May 2015

Spencer E, Searle P (2015) Cobalt market outlook. CRU. http://www. crugroup.com/market-analysis/products/cobaltmarketoutlook? TabId $=130087 \&$ Info $=$ Cobalt+Market+Outlook \&ReturnUrl $=$ n ull. Accessed May 2015

Sterman JD (2000) Business dynamics, system thinking and modelling for a complex world. Irwin McGraw-Hill, New York

Sverdrup H (2011) Peak minerals, peak energy, peak food, peak wealth, moving towards the end of a golden age. Bal Bull $1: 23-24$

Sverdrup H (2017) Modelling global extraction, supply, price and depletion of the extractable geological resources with the LITHIUM model. Resour Conserv Recycl 114:112-129

Sverdrup H, Ragnarsdottir KV (2014) Natural resources in a planetary perspective. Geochem Perspect October Issue 2:129-341. European Geochemical Society. http://www.geochemicalperspectives.org/online/v3n2. Accessed May 2015

Sverdrup H, Ragnarsdottir KV (2017) The future of platinum group metal supply; an integrated dynamic modelling for platinum group metal supply, reserves, stocks-in-use, market price and sustainability. Resour Conserv Recycl 114:130-152

Sverdrup H, Koca D, Granath C (2012a) Modeling the gold market, explaining the past and assessing the physical and economical sustainability of future scenarios. In: Schwanninger M, Husemann E, Lane D (eds) Proceedings of the 30th International Conference of the System Dynamics Society, St. Gallen, Switzerland, 22-26 July 2012. Model-based Management 5:4002-4023. University of St. Gallen, Switzerland; Systems Dynamics Society. Curran Associates, Inc. (ISBN: 9781622764143)

Sverdrup H, Koca D, Ragnarsdottir KV (2012b) The World 5 model; peak metals, minerals, energy, wealth, food and population; urgent policy considerations for a sustainable society. In: Schwanninger M, Husemann E, Lane D (eds) Proceedings of the 30th International Conference of the System Dynamics Society, St. Gallen, Switzerland, July 22-26, 2012. Modelbased Management 5:3975-4001, Curran Associates, Inc. (ISBN: 9781622764143)

Sverdrup H, Koca D, Ragnarsdottir KV (2013) Peak metals, minerals, energy, wealth, food and population; urgent policy considerations for a sustainable society. J Environ Sci Eng 499-534 (ISSN 2159-581X)

Sverdrup H, Koca D, Ragnarsdottir KV (2014a) Investigating the sustainability of the global silver supply, reserves, stocks in society and market price using different approaches. Resour Conserv Recycl 83:121-140

Sverdrup H, Ragnarsdottir KV, Koca D (2014b) On modelling the global copper mining rates, market supply, copper price and the end of copper reserves. Resour Conserv Recycl 87:158-174

Sverdrup H, Koca D, Ragnarsdottir KV (2015a) Aluminium for the future: modelling the global production, assessing long term supply to society and extraction of the global bauxite reserves. Resour Conserv Recycl 103:139-154

Sverdrup H, Ragnarsdottir KV, Koca D (2015b) An assessment of metal supply sustainability as an input to policy: security of supply extraction rates, stocks-in-use, recycling, and risk of scarcity. J Cleaner Prod. doi:10.1016/j.jclepro.2015.06.085

Sverdrup H, Koca D, Ragnarsdottir KV (2015c) Defining a free market: drivers of unsustainability as illustrated with an example of shrimp farming in the mangrove forest in South East Asia. J Clean Prod. doi:10.1016/j.jclepro.2015.06.087

Tainter JA (1990) The collapse of complex societies. Cambridge University Press, Cambridge

Tilton JE (1983) The impact of seabed nodules mining: a qualitative analysis. Research report. International Institute for Applied System Analysis (IIASA), Laxenburg. http://www.iiasa.ac.at/ Admin/PUB/Documents/RR-83-033.pdfS. Accessed May 2015

Tilton JE (2002) On borrowed time? Assessing the threat of mineral depletion. JHup Books. http://www.jhupbooks.com

Tilton JE (2009) Is mineral depletion a threat to sustainable mining? Presented at International Conference on Sustainable Mining, 17 Apr 2009, Santiago de Compostela, Spain

Tilton JE (2012) Is mineral depletion a threat to sustainable mining? Views III. Society of Economic Geologists Newsletter, vol 82

Tilton JE, Lagos G (2007) Assessing the long-run availability of copper. Resour Policy 32:19-23

UNEP (2011a) Recycling rates of metals - a status report. A report of the Working Group on the Global Metal Flows to the International Resource Panel. In: Graedel TE, Allwood J, Birat J-P, Reck BK, Sibley SF, Sonnemann G, Buchert M, Hagelüken C (eds), pp 48

UNEP (2011b) The International Resource Panel. In: Graedel TE, Buchert M, Reck K, Sonnemann G, UNEP Metal stocks in society; Scientific synthesis. Recycling rates of metals: a status report, pp 32 (ISBN 978-92-807-3182-0) 
UNEP (2011c) Metal stocks in society-scientific synthesis, A report of the Working Group on the Global Metal Flows to the International Resource Panel. In: Graedel TE (eds), pp 52

UNEP (2012) International Resource Panel: Responsible Resource Management for a Sustainable World. Findings of the International Resource Panel. (ISBN 978-92-807-3278-0)

UNEP (2013a) Metal recycling: opportunities, limits, infrastructure, A report of the Working Group on the Global Metal Flows to the International Resource Panel. In: Hudson C, van Schaik A, Heiskanen K, Meskers C, Hagelüken C (eds) Reuter, Massachusetts (ISBN: 978-92-807-3267-2)

UNEP (2013b) Environmental risks and challenges of anthropogenic metals flows and cycles, a report of the working group on the global metal flows to the international resource panel. In: van der Voet E, Salminen R, Eckelman M, Mudd G, Norgate T, Hischier R (ISBN: 978-92-807-3266-5)

UNEP (2013c) The International Resource Panel. In: Reuter M, Hudson C, Schalk A, Heiskanen K, Meskers C, Hagelüken C (eds) UNEP Metal recycling; Opportunities, Limits, Infrastructure (ISBN 978-92-807-3167-2)

USGS (2015) Commodity Statistics for a Number of Metals (Consulted Several Times 2008-2015). United States Geological Survey. http://minerals.usgs.gov/minerals/pubs/commodity/. Accessed 2005, 2007, 2008, 2012, 2013, 2014, 2015

Wagner H, Fettweis GBL (2001) About science and technology in the field of mining in the Western world at the beginning of a new century. Resour Policy 27:157-168
Walther JV (2014) Earth's natural resources. Jones and Bartless Learning, Burlington

Wellmer F-W (2008) Reserves and resources of the geosphere, terms so often misunderstood. Is the life index of reserves of natural resources a guide to the future? Z dt Ges Geowiss 159:575-590. Schweizerbart'sche Verlagsbuchhandlung, Stuttgart

Wellmer F-W, Becker-Platen JD (2007) Global nonfuel mineral resources and sustainability. In: Proceedings, Workshop on Deposit Modeling, Mineral Resource Assessment, and Sustainable Development US Department of the InteriorlUS Geological Survey. http://pubs.usgs.gov/circ/2007/1294/paper1.html. Accessed May 2015

Willburn DR (2015) Cobalt mineral exploration and supply from 1995 through 2013. Scientific Investigations Report 2011-5084. USGS. http://minerals.usgs.gov/minerals/pubs/commodity/ cobalt/. Accessed May 2015

Wübbeke J (2012) China's mineral and metals industry: on the path towards sustainable development? Pacific News 38:1-4

Zhou H (2007) The chemical environment of cobalt-rich ferromanganese crust deposits, the potential impact of exploration and mining on this environment, and data required to establish environmental baselines in the exploration areas. In: ISA (ed) Polymetallic sulphides and cobalt rich ferromanganese crust deposits: establishment of environmental base-lines and an associated monitoring programme during exploration, Proceedings of the International Seabed Authority's workshop, Kingston, 6-10 September 2004, 257-267 